\title{
Characterizing effects of hydropower plants on sub-daily flow regimes
}

\author{
María Dolores Bejarano, Álvaro Sordo-Ward, Carlos Alonso, Christer Nilsson
}

A B S T R A C T

A characterization of short-term changes in river flow is essential for understanding the ecological effects of hydropower plants, which operate by turning the turbines on or off to generate electricity following variations in the market demand (i.e., hydropeaking). The goal of our study was to develop an approach for characterizing the effects of hydropower plant operations on within-day flow regimes across multiple dams and rivers. For this aim we first defined ecologically meaningful metrics that provide a full repre-sentation of the flow regime at short time scales from free-flowing rivers and rivers exposed to hydropeaking. We then defined metrics that enable quantification of the deviation of the altered short-term flow regime variables from those of the unaltered state. The approach was successfully tested in two rivers in northern Sweden, one free-flowing and another regulated by cascades of hydropower plants, which were additionally classified based on their impact on short-term flows in sites of similar management. The largest differences between study sites corresponded to metrics describing sub-daily flow magnitudes such as amplitude (i.e., difference between the highest and the lowest hourly flows) and rates (i.e., rise and fall rates of hourly flows). They were closely followed by frequency-related met-rics accounting for the numbers of within-day hourly flow patterns (i.e., rises, falls and periods of stability of hourly flows). In comparison, between-site differences for the duration-related metrics were smallest. In general, hydropeaking resulted in higher within-day flow amplitudes and rates and more but shorter periods of a similar hourly flow patterns per day. The impacted flow feature and the characteristics of the impact (i.e., intensity and whether the impact increases or decreases whatever is being described by the metric) varied with season. Our approach is useful for catchment management planning, defining environmental flow targets, prioritizing river restoration or dam reoperation efforts and contributing information for relicensing hydropower dams.

Keywords:

Hydrological alterations

Hydrological characterization

Hydropeaking

Impact assessment

Short-term

Sub-daily flows

\section{Introduction}

Critical components of the flow regime such as magnitude, fre-quency, duration, timing and rate of change control ecological pro-cesses in river ecosystems (Poff et al., 1997), and modification of flow regimes constrains the distribution of species, their adaptive capacity, survival, dispersal and reproduction (Lytle and Poff, 2004). Each of these five flow components describes the variability over a wide range of spatial and temporal scales (Ward, 1989). Flow variability may be considered at long time scales, which are commonly controlled by inter- and intraannual variations in cli-mate. Year-to-year variation in flows associated to the Interdecadal Pacific Oscillation index and shifts in the El Niño Southern Oscilla-tion phenomenon (Biggs et al., 2005), and month-to-month variation in flows associated to seasons (Bejarano et al., 2010) are examples of large time-scale flow variability. Additionally, topography and geology are usually superimposed on climate and shape intra-annual flow variation in, for example, snowmeltfed or groundwater-fed rivers (Bejarano et al., 2010). Furthermore, flow variability may also be considered at shorter time scales, from months to hours (or smaller). Day-to-day and within-day water gains or losses are ultimately caused by varying rates of precipitation, evapotranspiration, infiltration, and snowmelt and by catchment characteristics such as drainage area, slope and land uses (Lundquist and Cayan, 2002; Archer and Newson, 2002), and can often be in the order of $10 \%$ of the mean daily flow in freeflowing rivers (Schuster et al., 2008). While these variations are small relative to the variability at annual time scales, they are still likely to be important to some stream ecosystem characteristics. Biggs et al. (2005) described how flow variation at these different temporal scales affects different ecosystem components and 
processes in rivers from New Zealand. They recognized that there may be a hierarchical relationship between time scales of flow variability and related physical processes, the effect of these physical processes on biological processes and, ultimately, the organization of ecosystem characteristics.

Rivers used for hydropower production usually show day-today and within-day flow variations that are considerably higher, more rapid and frequent than the ones characterizing freeflowing rivers. This is the result of turning hydro-turbines on or off to generate electricity based on variations in the market demand, so called hydropeaking (Moog, 1993), which has been recently promoted by the deregulation of the energy market. Additionally, changes in the short-term flow regimes are accompanied by changes in hydraulic parameters such as water level, flow velocity and bed shear stress, and in water quality and river morphology, and all together cause significant environmental losses in the fluvial systems. Although there are still many unknowns, studies have revealed significant effects of hydropeaking on fish, including low egg survival (Casas-Mulet et al., 2015), slow growth (Flodmark et al., 2004), reduced abundance (Korman and Campana, 2009), stranding (Saltveit et al., 2001), habitat deterioration (Vehanen et al., 2005) and changes in behavior (Robertson et al., 2004). A few studies have also pointed out heavy drift of macroinvertebrates (Carolli et al., 2012), and reductions in the occurrences of beetles (Van Looy et al., 2007) and macrophytes (Mjelde et al., 2013). Above all, hydropower is the world's leading form of renewable energy, and its demand is likely to increase globally as being a clean, flexible, and renewable energy source which does not produce greenhouse gases. Development of new hydropower plants is accelerating in Southeast Asia, Africa, and Latin America (Jager et al., 2015). In Europe, hydropower is being promoted by legislation such as the Renewable Energy Directive (RES; 2009/28/EC), which sets a legally binding national target of $20 \%$ of gross final energy consumption from renewable sources by 2020. In addition, in northern countries, climate change models predict future hydrographs to match power demands better, increasing the potential for producing more electricity (European Greenpower Marketing, 2006). Consequently, an important challenge for river management arises which involves maximizing hydropower production with minor ecological impacts. To cope with this demand for industry and society, assessment of the short-term changes in river flow following hydropeaking and of the resulting ecological responses is key. This paper deals with such assessment.

To evaluate the impact of hydropeaking resulting from hydropower production on short-term (e.g., sub-daily) flow regimes, it is necessary to characterize the within-day flow regime along the river reach affected by the hydropower plant and to quantify its deviation from the unaltered state. Metrics available are scarce and do not allow a comprehensive characterization of short-term flow regimes as they do not account for all hydrological attributes of ecological importance (Zimmerman et al., 2010; Meile et al., 2011; Haas et al., 2014; Sauterleute and Charmasson, 2014; Bevelhimer et al., 2015; Carolli et al., 2015; Chen et al., 2015). In addition, most proposed metrics are not conceived to quantify the degree of alteration. Research to date has focused on flow variability at the daily, seasonal and longer time scales (see review by Olden and Poff, 2003). Most characterizations of flow regimes, quantitative measures of their alterations, and tools and software available for calculations are based on daily-averaged flow records (e.g. Richter et al., 1996, 1997; Clausen and Biggs, 2000; Baker et al., 2004; Gao et al., 2009; Carlisle et al., 2011; Fitzhugh and Vogel, 2011), which are not precise enough to capture key components of sub-daily flow fluctuation. Long series of instantaneous flow records (e.g., every 15,30 or $60 \mathrm{~min}$ ) are required from both the altered and comparable free-flowing conditions for characterization of flow regimes at such shorter time scales and for evaluating the intensity of the changes.

The fact that these pairs of flow series are commonly difficult to find might have discouraged the studies on short-term flow regimes up to date, though this situation is reverting in recent times. Thus, new methods are needed to comprehensively describe all facets of within-day flow regimes and assess their degree of deviation from the natural conditions, to identify dams that artificially modify natural sub-daily variations and river reaches that are likely to experience ecological degradation because of it. Such analyses are useful for catchment management plans, defining environmental flow targets, prioritizing river restoration or dam reoperation efforts and contributing information for relicensing hydropower dams. The goal of our study was to develop an approach for assessing the effects of hydropower dam operations on within-day flow regimes across multiple dams and rivers. For this aim we first defined ecologically meaningful metrics that provide a full representation of the short-term variation of flow in free-flowing rivers and rivers exposed to hydropeaking. We then defined metrics that enable quantification of the deviation of the characterized altered short-term flow regime from the unaltered state. We applied devised characterization and impact metrics to several study sites along a free-flowing river and a river with hydropeaking (at hydropower plant locations) and, with management facilitation purposes, we classified them according to their short-term flow regime alterations.

\section{Material and methods}

\subsection{Study area and flow data}

The study was located to the Vindel and Ume rivers in the Ume River basin in northern Sweden (Fig. 1). The Vindel River is the main tributary of the Ume River; it runs parallel to the Ume and joins it about $30 \mathrm{~km}$ upstream of the mouth in the Baltic Sea. Both rivers show similar characteristics. The whole Ume basin is characterized by cold-temperate climate, boreal coniferous vegetation and podzol soils. The upland vegetation consists of subalpine birch forests dominated by Betula pubescens, and coniferous forests dominated by Pinus sylvestris and Picea abies. The riparian vegetation includes woody species such as Alnus incana, B. pubescens and Salix spp., and herbs such as Carex spp. and Ranunculus reptans. The Vindel and Ume rivers have catchment areas encompassing 13,183 and $13,633 \mathrm{~km}^{2}$, respectively, their channel lengths are 445 and $455 \mathrm{~km}$, and their natural mean monthly flows (at the junction) 197 and $239 \mathrm{~m}^{3} / \mathrm{s}$. Whereas the flow regime of the Vindel River remains unaltered, the Ume River flow is highly impacted by a chain of hydropower plants and reservoirs which cause hydropeaking (Fig. 2). The free-flowing regime experiences a marked seasonal variation with low flows during late autumn and winter and floods during spring. Within a day, the free-flowing regime is relatively smooth and only fluctuates significantly after water additions or losses resulting from significant precipitation, evapotranspiration, infiltration and snowmelt events. In contrast, dams and reservoirs alter both the long- and short-term flow regimes of the Ume River; whereas the natural seasonality of flows is attenuated, the withinday flows fluctuate abruptly (Fig. 2). We selected three sites along the Vindel River [from upstream to downstream: Gautsträsk (U; $33 \mathrm{~m}^{3} / \mathrm{s}$ mean annual flow), Sorsele (S; $119 \mathrm{~m}^{3} / \mathrm{s}$ ) and Granåker $\left.\left(\mathrm{K} ; 176 \mathrm{~m}^{3} / \mathrm{s}\right)\right]$ and eight sites along the Ume River coinciding with dam and reservoir locations [Grundfors ( $G ; 187 \mathrm{~m}^{3} / \mathrm{s}$ ), Rusfors (R; $\left.213 \mathrm{~m}^{3} / \mathrm{s}\right)$, Bålforsen $\left(\mathrm{L} ; 215 \mathrm{~m}^{3} / \mathrm{s}\right)$, Betsele $\left(B ; 218 \mathrm{~m}^{3} / \mathrm{s}\right)$, Tuggen (T; $\left.222 \mathrm{~m}^{3} / \mathrm{s}\right)$, Bjurfors övre $\left(0 ; 227 \mathrm{~m}^{3} / \mathrm{s}\right)$, Bjurfors nedre $(\mathrm{N}$; $\left.232 \mathrm{~m}^{3} / \mathrm{s}\right)$ and Harrsele $\left.\left(\mathrm{H} ; 235 \mathrm{~m}^{3} / \mathrm{s}\right)\right]$ where 15 -min and 1 -h interval flows were available, respectively (Fig. 1). For the 


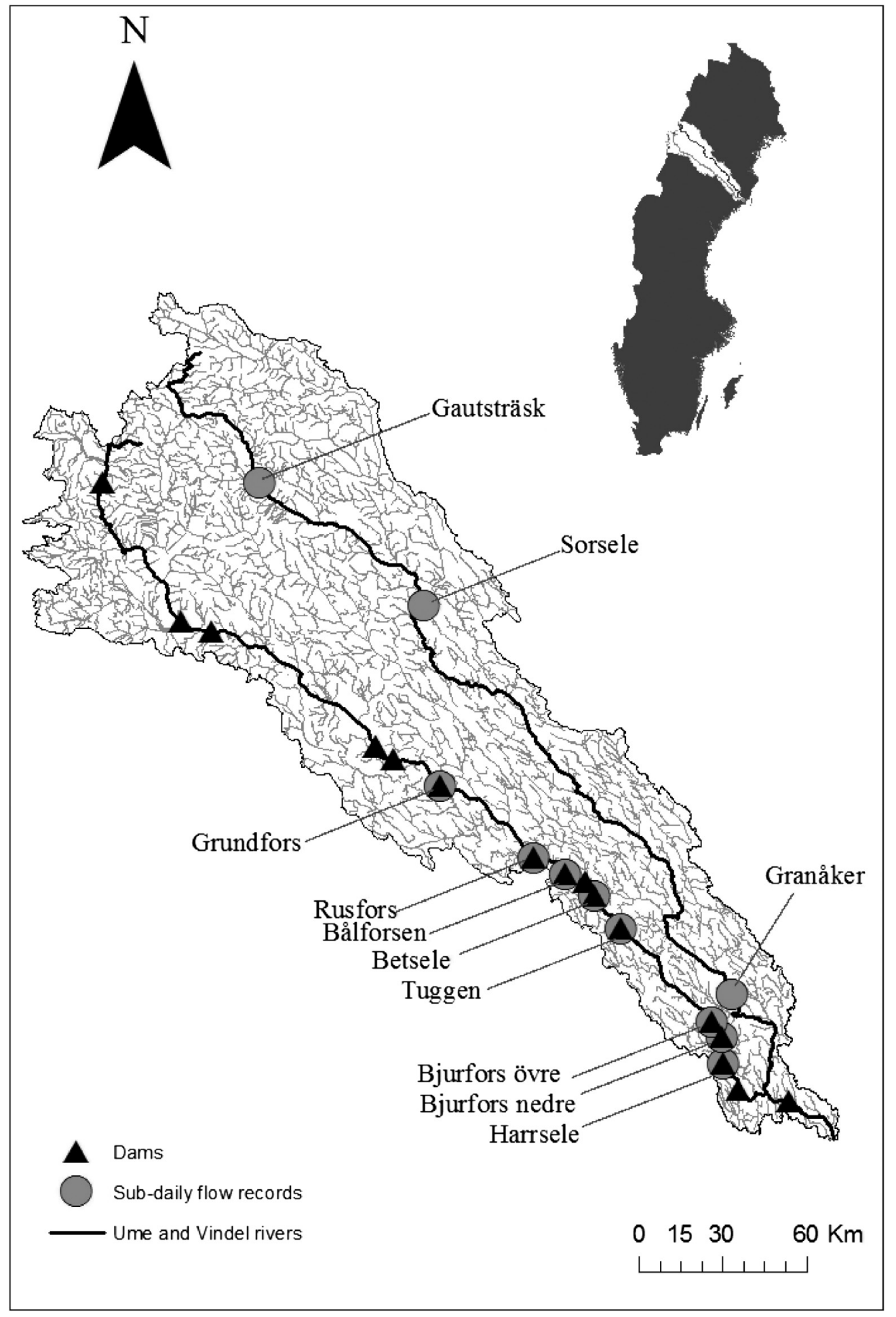

Fig. 1. Location map. The name of the sites where the proposed approach was tested (grey circles) are indicated on the map.

short-term flow regime characterization and alteration assessment we chose a 9-year period (2003-2011) of sub-daily flow records, common to both rivers.

\subsection{Short-term flow regime characterization and alteration assessment}

Our first goal was to characterize the daily flow variation. We therefore defined a series of hydrological metrics based on 1-h flow intervals, named Short-Term Characterization Metrics (STCM; Table 1). For the metrics definition, the within-day hydrograph was divided into hours $(\mathrm{H})$ and periods $(\mathrm{P})$. A within-day hourly hydrograph is characterized by $24 \mathrm{~h}(\mathrm{H})$ with individual flow records, $Q h$, which can be assigned one of the following patterns: (1) rise $(\mathrm{RH})$, when $\mathrm{Q}_{(\mathrm{h})}-\mathrm{Q}_{(\mathrm{h}-1)}>0$; (2) fall $(\mathrm{FH})$, when $\mathrm{Q}_{(\mathrm{h})}-\mathrm{Q}_{(\mathrm{h}-1)}<0$; (3) stability $(\mathrm{SH})$ when $\mathrm{Q}_{(\mathrm{h})}-\mathrm{Q}_{(\mathrm{h}-1)}=0$; (4) change $(\mathrm{CH})$, when the pattern in $\mathrm{Q}_{(\mathrm{h}-1)} \neq$ the pattern in $\mathrm{Q}_{(\mathrm{h}+1)}$; (5) minimum (MinH), when $\mathrm{Q}_{(\mathrm{h})}=\mathrm{Q}_{(\min )}$; and (6) maximum $(\mathrm{MaxH})$, when $\mathrm{Q}_{(\mathrm{h})}=\mathrm{Q}_{(\max )}$. 


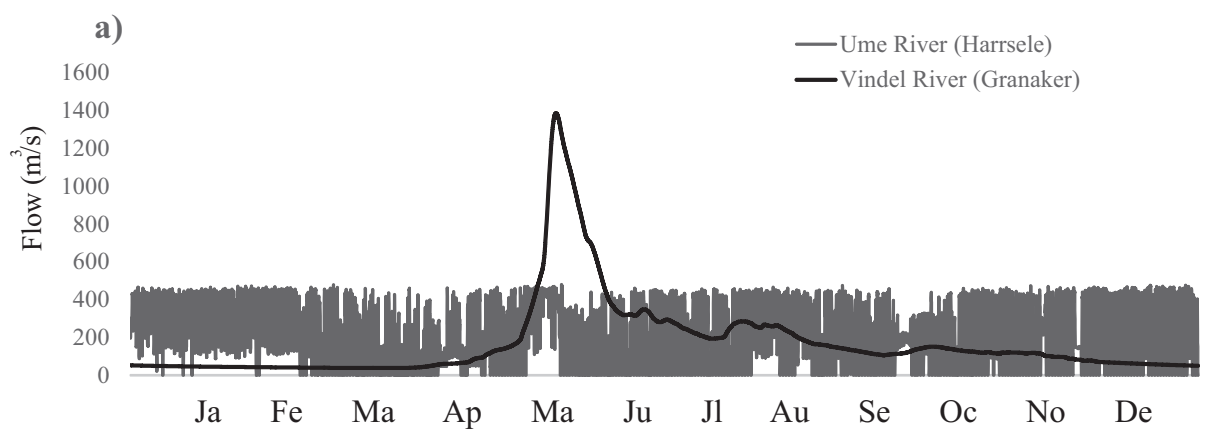

b)

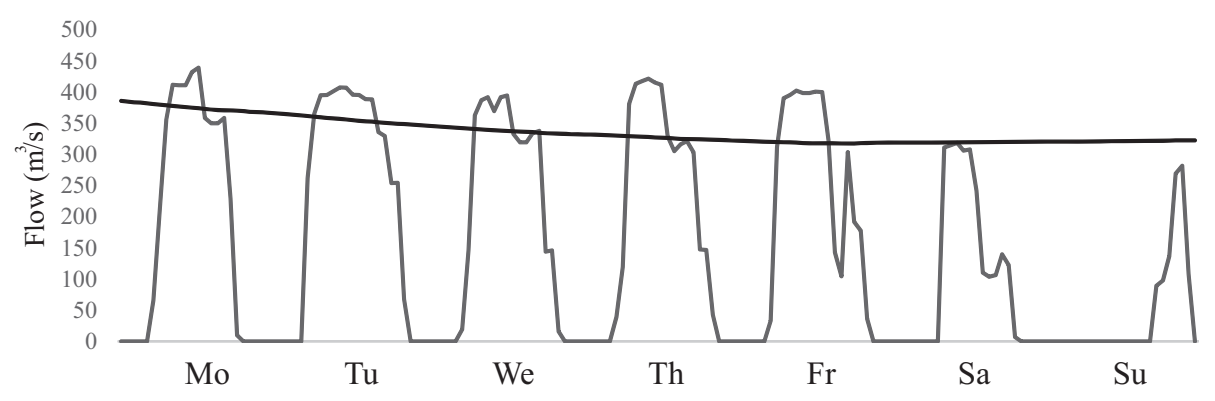

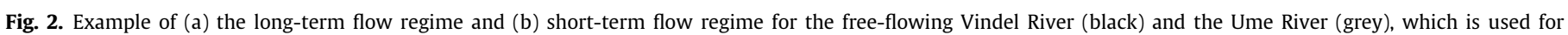
hydropower production. The x-axis shows (a) the months and (b) the days of the week.

Where $h$ is the 1 -h time step and min, and max are the daily hourly minimum and maximum, respectively. One to several periods $(P)$ of stable flow among hours (cf. above) can be identified in a within-day hydrograph. Therefore, $\mathrm{P}$ denotes flow events lasting between one and $24 \mathrm{~h}$ and which can be classified according to the hourly pattern into periods of rise (RP), fall (FP), stability (SP), minimum (MinP), and maximum (MaxP). STCM were developed to quantify magnitudes, rates of change, frequencies, durations and timing of $P$ from each day of the year (i.e., ith day of the year) (see Table 1 for detailed information on STCM). For several-year long series (i.e., $n$ years of the series), each metric was computed as daily average for the whole dataset (Eq. (1)).

$$
\operatorname{STCM}_{\text {day }(i)}=\frac{\sum_{j=1}^{j=n} \operatorname{STCM}_{\operatorname{day}(i, j)}}{n}
$$

Consequently, there are 365 (or 366 for leap years) values for each characterization metric. When flow records were available for shorter time steps, such as 15-min intervals, they were transformed into hourly flows by selecting only o'clock times. STCM describing magnitude and rate-related features were previously standardized by dividing between the mean hourly flow for the dataset, which facilitates further comparisons with other river reaches of different size. Similar to parameters defined by Richter et al. (1996) for the characterization of long-term flow regime, our STCM were assumed relevant for the biotic composition of aquatic, wetland, and riparian ecosystems (Poff et al., 1997). Table 2 briefly summarizes the main changes in the environment and responses of organisms resulting from the alteration of the shortterm flow regimes, which have been reported in previous studies. Derived ecological consequences include reduced performance, slowed growth, and increased mortality of individuals, and ultimately decreased species diversity, community composition shifts, and eventually, exotic species invasion (see Table 2 for further details and references). Such changes have been highlighted to be very dependent on the species, age, life-stage and river morphology (Scruton et al., 2003; Roni et al., 2008; Tuhtan et al., 2012; Hauer et al., 2014).
We aimed for an evaluation of the short-term flow-regime alteration of the river reaches subjected to hydropower production, and hence affected by hydropeaking. Our approach was based on the comparison of the whole suite of STCM for pairs of similar river reaches, one with hydropeaking and the other free-flowing. We aimed at identifying the type of impact, as the attributes that were most impacted by the short-term flow regime, and the intensity and sign of the impact, as the degree of deviation from the reference condition and whether the impact increases or decreases whatever is being described by the metric. Type, intensity and sign of the short-term hydrological alteration are essential for understanding its potential ecological consequences. We developed a suite of Short-Term flow regime Impact Metrics (STIM) following Eqs. (2), (3) and (4).

$\overline{S T C M}=\frac{\sum_{i=1}^{i=365} S_{T C M} M_{\text {day }(i)}}{365}$

If $\frac{S T C M_{\text {day }(i)(h p)}-S T C M_{\text {day }(i)(f f)}}{\overline{S T C M} M_{(f f)}} \geqslant 0$

$\mathrm{STIM}_{\text {day }(i)}=\log _{10}\left(\frac{\operatorname{STCM}_{\operatorname{day}(i)(h p)}-\mathrm{STCM}_{\operatorname{day}(i)(f f)}}{\operatorname{STCM}(f f)}+1\right)$

If $\frac{S T C M_{\operatorname{day}(i)(h p)}-S T C M_{\operatorname{day}(i)(f f)}}{S T C M_{(f f)}}<0$

$\operatorname{STIM}_{\text {day }(i)}=\left[\log _{10}\left(/ \frac{\operatorname{STCM}_{\text {day }(i)(h p)}-\operatorname{STCM}_{\operatorname{day}(i)(f f)}}{\operatorname{STCM}(f f)} /+1\right)\right] *(-1)$

where $h p$ and $f f$ are the hydropeaking and free-flowing hourly flow series, respectively. Each impact metric quantifies the deviation from the reference condition of the corresponding characterization metric (Eqs. (3) and (4)), and the intensity of the impact is relative to the yearly average of that metric in the reference conditions (Eq. (2)). $\log _{10}$ was applied to the quotient to avoid excessively high values when the yearly average of certain metrics in the reference conditions are very low (e.g., metrics related to flow rates of change). Impact metrics can take any positive (Eq (3)) and negative value (Eq (4)). Further details on STIM are shown in the Table 1. 
Table 1

Description of the proposed Short-Term Characterization and Impact Metrics (STCM and STIM)

\begin{tabular}{|c|c|c|}
\hline & $\begin{array}{l}\text { Metric's name, } \\
\text { abbreviation and units }\end{array}$ & Metric's definition \\
\hline \multirow[t]{6}{*}{ Frequency } & $\begin{array}{l}\text { Total periods of rise } \\
\text { (TRP; \#periods/day) }\end{array}$ & $\begin{array}{l}\text { Daily mean total periods } \\
\text { characterized by a sustained over } \\
\text { time hourly flow rise }\end{array}$ \\
\hline & $\begin{array}{l}\text { Total periods of fall (TFP; } \\
\text { \#periods/day) }\end{array}$ & $\begin{array}{l}\text { Daily mean total periods } \\
\text { characterized by a sustained over } \\
\text { time hourly flow fall }\end{array}$ \\
\hline & $\begin{array}{l}\text { Total periods of stability } \\
\text { (TSP; \#periods/day) }\end{array}$ & $\begin{array}{l}\text { Daily mean total periods } \\
\text { characterized by a sustained over } \\
\text { time hourly flow stability }\end{array}$ \\
\hline & $\begin{array}{l}\text { Total periods of } \\
\text { minimum (TMinP; } \\
\text { \#periods/day) }\end{array}$ & $\begin{array}{l}\text { Daily mean total periods } \\
\text { characterized by a sustained over } \\
\text { time that day's hourly minimum } \\
\text { flow }\end{array}$ \\
\hline & $\begin{array}{l}\text { Total periods of } \\
\text { maximum (TMaxP; } \\
\text { \#periods/day) }\end{array}$ & $\begin{array}{l}\text { Daily mean total periods } \\
\text { characterized by a sustained over } \\
\text { time that day's hourly maximum } \\
\text { flow }\end{array}$ \\
\hline & $\begin{array}{l}\text { Total hourly reversals } \\
\text { (TR; \#reversals/day) }\end{array}$ & $\begin{array}{l}\text { Daily mean total rises and falls of } \\
\text { hourly flows }\end{array}$ \\
\hline \multirow[t]{5}{*}{ Duration } & $\begin{array}{l}\text { Duration periods of rise } \\
\text { (DurRP; h/day) }\end{array}$ & $\begin{array}{l}\text { Daily mean duration of the periods } \\
\text { characterized by a sustained over } \\
\text { time hourly flow rise }\end{array}$ \\
\hline & $\begin{array}{l}\text { Duration periods of fall } \\
\text { (DurFP; h/day) }\end{array}$ & $\begin{array}{l}\text { Daily mean duration of the periods } \\
\text { characterized by a sustained over } \\
\text { time hourly flow fall }\end{array}$ \\
\hline & $\begin{array}{l}\text { Duration periods of } \\
\text { stability (DurSP; h/day) }\end{array}$ & $\begin{array}{l}\text { Daily mean duration of the periods } \\
\text { characterized by a sustained over } \\
\text { time hourly flow stability }\end{array}$ \\
\hline & $\begin{array}{l}\text { Duration periods of } \\
\text { minimum (DurMinP; } \\
\text { h/day) }\end{array}$ & $\begin{array}{l}\text { Daily mean duration of the periods } \\
\text { characterized by a sustained over } \\
\text { time that day's hourly minimum } \\
\text { flow }\end{array}$ \\
\hline & $\begin{array}{l}\text { Duration periods of } \\
\text { maximum (DurMaxP; } \\
\text { h/day) }\end{array}$ & $\begin{array}{l}\text { Daily mean duration of the periods } \\
\text { characterized by a sustained over } \\
\text { time that day's hourly maximum } \\
\text { flow }\end{array}$ \\
\hline \multirow[t]{5}{*}{$\begin{array}{l}\text { Magnitude } \\
\quad \& \text { rate }\end{array}$} & $\begin{array}{l}\text { Mean amplitude } \\
\text { (MeanA; unitless) }\end{array}$ & $\begin{array}{l}\text { Standardized daily mean of the } \\
\text { difference between maximum and } \\
\text { minimum hourly flows }\end{array}$ \\
\hline & $\begin{array}{l}\text { Mean minimum periods } \\
\text { of stability (MeanMinSP; } \\
\text { unitless) }\end{array}$ & $\begin{array}{l}\text { Standardized daily mean } \\
\text { minimum flow of periods } \\
\text { characterized by a sustained over } \\
\text { time hourly flow stability }\end{array}$ \\
\hline & $\begin{array}{l}\text { Mean maximum periods } \\
\text { of stability (MeanMaxSP; } \\
\text { unitless) }\end{array}$ & $\begin{array}{l}\text { Standardized daily mean } \\
\text { maximum flow of periods } \\
\text { characterized by a sustained over } \\
\text { time hourly flow stability }\end{array}$ \\
\hline & $\begin{array}{l}\text { Mean rise rate (MeanRR; } \\
\text { unitless) }\end{array}$ & $\begin{array}{l}\text { Standardized daily mean hourly } \\
\text { flow rise rate }\end{array}$ \\
\hline & $\begin{array}{l}\text { Mean fall rate (MeanFR; } \\
\text { unitless) }\end{array}$ & $\begin{array}{l}\text { Standardized daily mean hourly } \\
\text { flow fall rate }\end{array}$ \\
\hline
\end{tabular}

\subsection{Data analysis}

STCM were computed for the 9-year hourly flow series from the 11 selected sites to describe their short-term flow regimes. We conducted an exploratory analysis of the hourly flow records and of the STCM using duration curves and plotting the metrics against flows. Additionally, we looked for the correlated metrics as those with Spearman's Correlation Index higher than \pm 0.7 . Based on the STCM, the series of STIM was computed for the eight sites at the Ume River to evaluate the type, intensity and sign of short-term alteration resulting from hydropeaking. According to their hydrological and physical characteristics, Sorsele and Granåker sites in the Vindel River were selected as references for the upper site (i.e., Grundfors) and for the remaining sites (i.e., from upstream to downstream: Rusfors, Bålforsen, Betsele, Tuggen, Bjurfors övre, Bjurfors nedre, and Harrsele) in the Ume River, respectively (Fig. 1). Non-existent hourly flow records in the flow series from each site were interpolated with the previous and following records.

We searched for significant differences among sites for the characteristics and the alteration of their short-term flow regimes by running Kruskal-Wallis tests followed by the Games-Howell $(\mathrm{GH})$ post hoc test on the sites' STCM and STIM $(P<0.05$ for significant results). Afterwards, regulated sites were classified based on the impact of hydropeaking on their short-term flow regimes. On the one hand, we ranked the regulated sites based on the type and intensity of the impact. For this, we averaged the absolute values of the annually averaged impact metrics referring to all or each of the aspects of the flow regime and classified sites in four categories as slightly, moderately, highly, and strongly impacted. On the other hand, we classified the sites per type, intensity, sign and timing of the impact of each site's short-term flow regime. For this, we carried out hierarchical cluster analysis using the Ward method on the seasonally averaged impact metrics from each site for all or each of the flow regime aspects. Statistics were performed in SPSS 23. We used Matlab 2015 for metric calculations.

\section{Results}

\subsection{Characterization of short-term flow regimes}

We defined 16 STCM (Table 1). Six metrics described frequency aspects of the short-term flow regime, and 5 described magnitude and rate, and duration aspects, each. Information about timing was also provided as each metric showed a value for each day of the year. Eleven out of the 16 metrics were uncorrelated (Supplementary information S1). The number of periods of rise and fall (TRP and TFP), respectively, were positively correlated, so were the numbers of hourly reversals (TR) to both metrics, and the mean amplitude of hourly flows (MeanA) to the number of periods of rise. Furthermore, the mean amplitude was negatively correlated to the mean rise rate of hourly flows (MeanRR). Rise and fall (MeanFR) rates of hourly flows were also negatively correlated. Finally, the duration of periods of maximum and stability (DurMaxP and DurSP) were positively correlated. $1 \%$ of the flow data were interpolated. Duration curves for the hourly flows and characterization metrics highlighted the significant differences between free-flowing and hydropeaking sites. The analyzed hydropower systems were designed to operate efficiently across the medium range of flows (i.e., around Q10\%-Q80\%), causing higher percentages of exceedance than in natural conditions (Fig. 3). They are also able to cope and efficiently operate at higher flows (i.e., Q1\%-Q10\%), up to the very rare extreme flood events (i.e., Q0\%Q1\%) when water is spilled. Finally, they operate at a low power output or begin to shut down at the lower flows (i.e., Q80\%Q100\%). Across these high and low flow ranges the operation results into lower percentages of exceedance than in natural conditions (Fig. 3). During the optimum range of the plant operation, most of the characterization metrics oscillated over a narrow range of values which were higher than for natural flow regimes. This is shown by the steeper slopes and upper position of the duration curves of the metrics from the hydropeaking sites between STCM10\%-STCM80\% (Fig. 4), as well as by the unscattered cloud of hydropeaking metrics values above those from the freeflowing sites (Supplementary information S2). Some durationrelated metrics, however, were lower in hydropeaking than in free-flowing regimes from a certain percentage of exceedance of the metric (e.g., DurRP or DurFP; Fig. 4). Additionally, unlike in the free-flowing sites, the metrics' lowest values (i.e., above STCM80\%) in the hydropeaking sites did not equal zero for most cases and the majority of them were exceeded almost $100 \%$ of the time (Fig. 4). 
Table 2

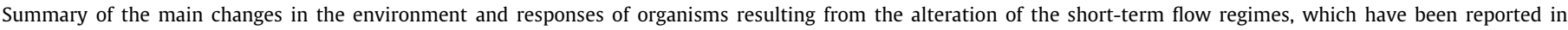
representative studies.

Flow feature and alteration

Frequency Increased within-day number of reversals

Increased within-day number of periods of flow rise, and of maximum flows

Magnitude Increased within-day magnitude of periods of maximum flows

Decreased within-day magnitude of periods of minimum flows
Changes on environment and responses of organisms

Fish behavioral changes including very active fish which show many non-migratory short movements (e.g., constant change from resting on substrate to swimming in the water column, and search for suitable habitats). This implies higher fish energy consumption.

Fish habitat persistence undermined, involving transient shelters and food, which increases competence with neighboring fish and reduces food uptake.

Increased scouring capabilities of moving water and ice, which damages or removes sessile organisms or life stages, such as fish eggs, aquatic macroinvertebrates and aquatic and riparian plants. Increased turbidity, which affects adversely fish movement and health by clogging gill rakers and gill filaments, and hampers aquatic and riparian plants photosynthesis.

High prey (e.g., invertebrates) availability, which results in more food for fish.

Frequent inundation of riparian areas causing soil waterlogging and frequent partial or total submergence. This affects aquatic and riparian plants by attenuating light, hampering gas exchange and causing anoxia.

Fish migratory changes such as increased upstream migration.

Fish habitat deterioration or improvement. Deterioration through substrate mobilization; improvement through maximizing oxygen supply when promoting flushing of fine sediment from gravel. Fish egg damage and removal.

Macroinvertebrate removal.

Increased scouring capabilities of high flows, which damages or removes sessile organisms or life stages, such as fish eggs, macroinvertebrates and plants directly or indirectly through soil erosion and changes in channel morphology.

Reduction of suitable habitats available for fish due to lower volume of water in the river and reduction in average depth and width of the river channel, which result in oxygen stress and cause problems with fish refuge and feeding.

Habitat deterioration following siltation of gravel and reduced oxygen, which affects fish spawning.

Fish migratory changes both upstream and downstream due to too little water that impedes fish movement

Elevated fish density due to inability to redistribute themselves. Fish restricted to wetted ponds, which may lead to cannibalism, limited

feeding, and higher transmission of pathogens

Fish egg desiccation or freezing (in winter).

Indirect effects on fish of increased water temperature

Desiccation of macroinvertebrates.

Soil moisture deficit and water stress for aquatic and riparian plants.

Rates

Rapid within-day flow decrease Fish stranding

Deposition of plant propagules and soil. Seeds and vegetative parts on newly deposited surfaces favor plant establishment, but soil deposition also results into coating mud, burial, and soil surface clogging. Hampered germination.

Rapid within-day flow increase Fish drift.

Macroinvertebrate drift (catastrophic drift).

Increased aquatic and riparian plant propagules dispersal. Hampered germination.

Duration Shorter within-day periods of flow rise and fall

Longer within-day periods of minimum and maximum flows
That such periods are shorter implies less time for key activities of fish such as feeding in the water column or resting on substrate, which ultimately results in less food uptake and higher fish energy consumption.

That such periods are longer exacerbates their above-described effects For example, likelihood of fish egg desiccation and death following stranding increases with duration of low flow periods. Similarly, likelihood of death of riparian or aquatic plants increases when they remain under water or emerged for a long period, respectively.
References

Scruton et al. (2003), Taylor et al. (2014), Capra et al. (2016), Boavida et al. (2017)

Freeman et al. (2001), Flodmark et al. (2004)

Jensen and Johnsen (1999), Friedman and Auble (1999), Madsen et al. (2001), Lind et al. (2014) Bruton (1985), Kirk (1994)

Rocaspana et al. (2016), Kelly et al. (2017) Ernst (1990), Armstrong et al. (1994)

Taylor and Cooke (2012)

Jensen and Johnsen (1999)

Jensen and Johnsen (1999), Gostner et al. (2011)

Gostner et al. (2011), Miller and Judson (2014)

Friedman and Auble (1999), Madsen et al. (2001)

Vollset et al. (2016)

Cowx et al. (1998), Levasseur et al. (2006)

Armstrong et al. (2003)

Smith and Reay (1991)

Milner et al. (2003), Casas-Mulet et al. (2015)

Elliott et al. (1997), Wootton (1998)

Holzapfel et al. (2016)

Garcia de Jalón et al. (1998), Porporato et al. (2001), Stella et al. (2010), Mjelde et al. (2013)

Saltveit et al. (2001), Irvine et al. (2009),

Tuhtan et al. (2012), Hauer et al. (2014),

Boavida et al. (2015)

Goodson et al. (2003), Pettit and Naiman (2006)

Baldwin et al. (2001)

Wolter and Sukhodolov (2008)

Timusk et al. 2016; Bruno et al. 2016;

Leitner et al. (2017), Gostner et al. (2011)

Boedeltje et al. (2004)

Baldwin et al. (2001)

Capra et al. (2016), Boavida et al. (2017)

Warren et al. (2015), Casanova and Brock (2000) 
Table 2 (continued)

Flow feature and alteration

Timing Seasonality of short-term flow changes
Changes on environment and responses of organisms

Increased fish drift and stranding risk during winter.

Increased fish migratory and non-migratory behavioral changes during summer.

Freezing of eggs during winter.

Low flows naturally taking place in winter reduce drift and favor benthic feeding, which is more profitable than drift feeding due to the lower cost of not having to maintain a position in the current. Getting the same amount of food under higher winter drift implies more energy expenditure.

Timing of life stages of aquatic insects and aquatic and riparian plants determines how they are affected by short-term flow changes. For example, short-term flow alterations coinciding with adult egg-laying behavior such that open-water layers or with plants dispersal will not have major effects, whereas alterations coinciding with river-edge layers, such as mayflies, or with seed germination will cause severe impact.

\section{References}

Saltveit et al. (2001), Halleraker et al. 2003; Irvine et al. (2015)

Puffer et al. (2015)

Heggenes et al. (2016)

Castro et al. (2013), Kennedy et al. (2016)

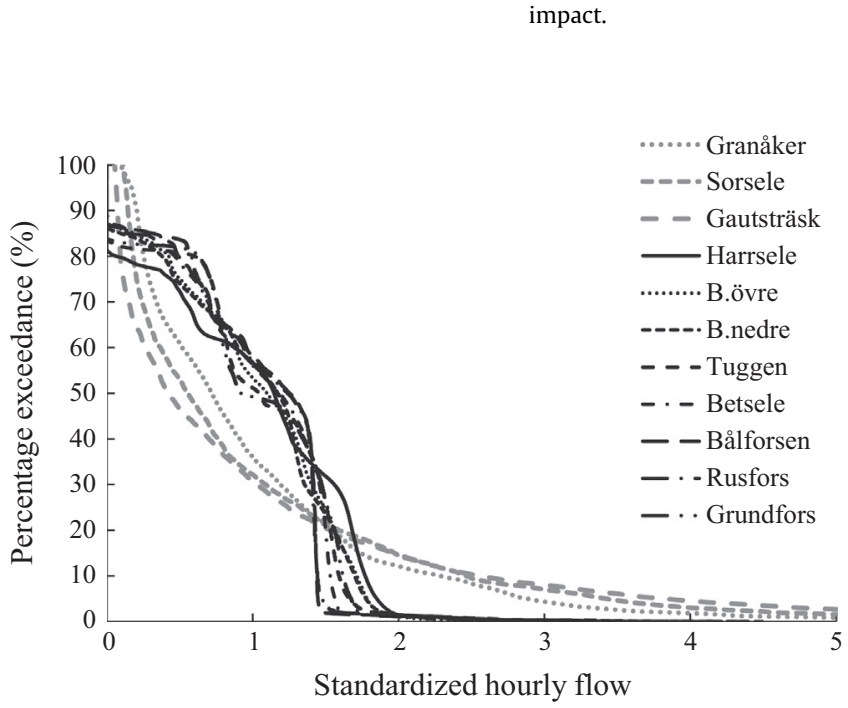

Fig. 3. Flow duration curve for hourly flows recorded at each studied site. Grey lines represent the free-flowing sites, whereas the black lines represent the hydropeaking sites. Note that the maximum standardized flows from the free-flowing sites are 20.1 (Gautsträsk), 10.0 (Sorsele) and 7.9 (Granåker), but for representation purposes, the $\mathrm{x}$-axis only contains standardized flows up to 5 .

All characterization metrics were significantly different between sites ( $p<0.05$; Fig. 5; Supplementary information S3). Post-hoc tests revealed that all characterization metrics differed significantly between the free-flowing and hydropeaking sites (differences of the metric values are seen rightward and leftward of the vertical dashed line in Fig. 5). However, some metrics were similar for free-flowing and hydropeaking sites, such as TSP, TMinP, DurMinP, DurMaxP and MeanMaxSP (Fig. 5; Supplementary information S3). In addition, some metrics differed significantly within the pool of hydropeaking sites (leftward of the dashed line) or within the pool of free-flowing sites (rightward of the dashed line; Fig. 5). For example, most of the sites showed significantly different values for TFP, DurFP, MeanA and MeanRR, whereas MeanMinSP was significantly higher in the free-flowing sites compared to the hydropeaking sites but barely differed among the hydropeaking ones (Fig. 5). As shown by the width of the boxes in Fig. 5, in general, metrics characterizing the freeflowing sites varied along the year more than in the hydropeaking sites (Fig. 5). Seasonally averaged characterization metrics values are detailed in Supplementary information S4.

As general patterns, most hydropeaking sites showed more periods of rise and fall (TRP and TFP) and less periods of stability (TSP) per day than the free-flowing sites. Some upstream hydropeaking sites, however, were similarly or more stable per day than the free-flowing ones (Fig. 5). The frequency of hourly reversals per day (TR) was remarkably higher in the hydropeaking sites than in the free-flowing sites (Fig. 5). Despite being more frequent, periods of rise and fall per day were considerably shorter in the hydropeaking sites compared to the free-flowing sites (Fig. 5). Periods of stability were of similar duration for the downstream hydropeaking and free-flowing sites and slightly longer for the most upstream hydropeaking sites (Fig. 5). There were no differences in the daily frequencies of the periods of minimum and maximum (TMinP and TMaxP) between free-flowing and hydropeaking sites, and their durations were slightly different. Most magnitude metrics showed higher dispersion in the free-flowing sites (Fig. 5). Whereas the median for the mean daily hourly amplitude (MeanA), and for the daily periods of flow stability's maximum value (MeanMaxSP) was significantly higher along hydropeaking sites (Fig. 5), the median for the minimum daily value of flow stability (MeanMinSP) was significantly lower in the hydropeaking sites compared to the free-flowing ones. Hourly flows rose and fell (MeanRR and MeanFR) significantly faster under hydropeaking conditions (Fig. 5).

\subsection{Assessment of short-term flow regimes alteration}

There were 16 STIM, each corresponding to a STCM (Table 1). Impact metrics ranged between -0.5 and 2 (Fig 6). Between sites comparisons of the impact metrics showed the following results. Rates were similarly impacted in all sites (i.e., $P>0.05$ for MeanRR-I and MeanFR-I; Fig. 6; Supplementary information S5). Among significantly different impact metrics $(P<0.05)$, some duration related metrics only differed in one or two sites such as DurFPI and DurMaxP-I, whereas others differed in many of the sites (TRPI, TFP-I, TR-I, DurMinP-I, MeanA-I, and MeanMinSP-I; Fig. 6 and Supplementary information S5). Seasonally averaged impact metric values are detailed in Supplementary information S6. Below follows a detailed evaluation of the impacts on the different metrics.

Frequency related features were in general moderately impacted (Fig 6). As shown by the relatively high positive value of the impact on the number of periods of rise and fall and hourly reversals per day (TRP-I, TFP-I and TR-I), these events tended to be much more frequent in the sites subjected to hydropower production than in the free-flowing ones, being the impact higher as we move downstream (Fig. 6). The seasonal analysis of these metrics also highlights that the impact was most evident during autumn and winter (Fig. 6). The frequency of periods of stability per day (TSP-I) was impacted oppositely in the downstream and upstream sites. In general, whereas it slightly decreased downstream and 

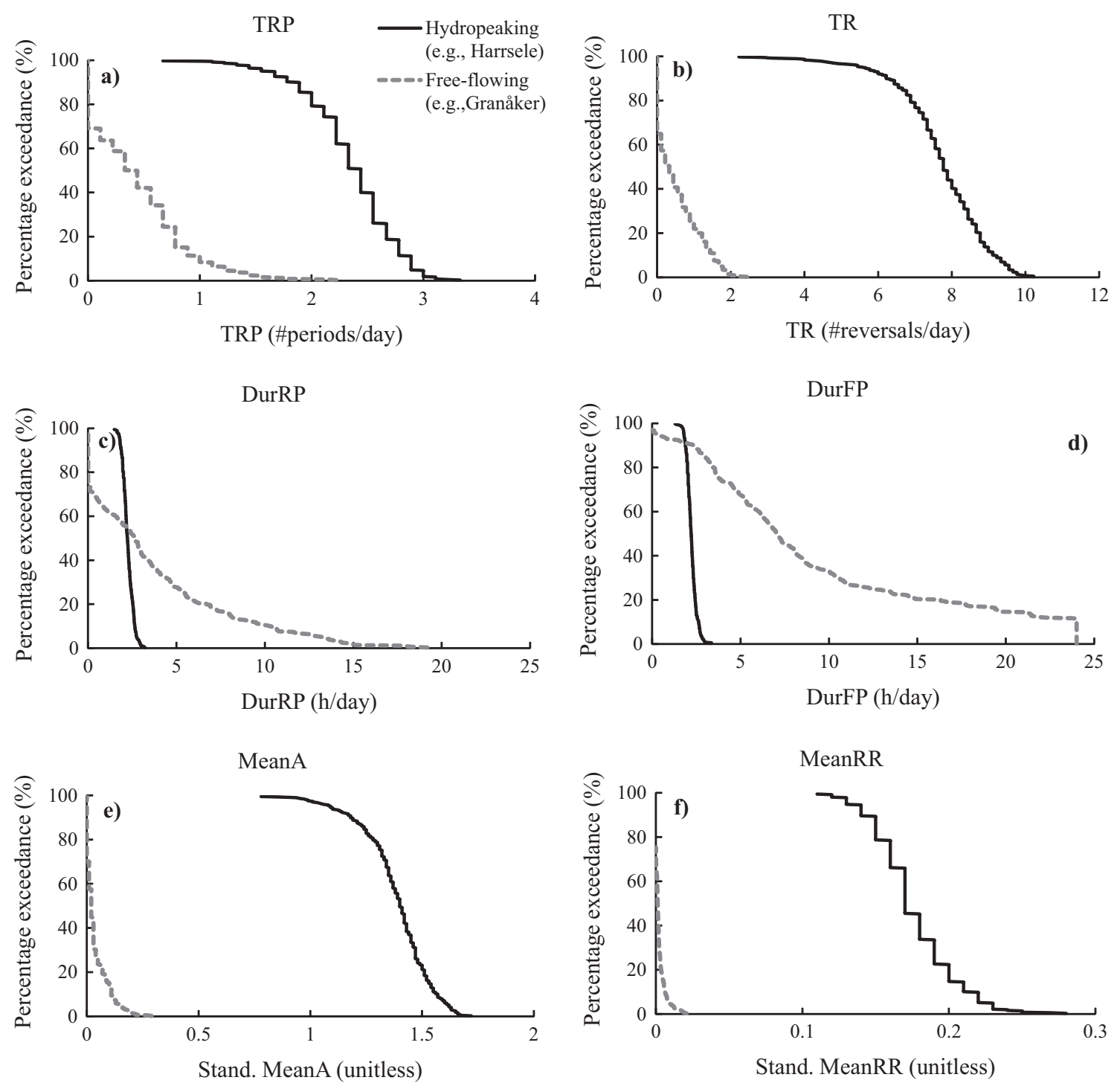

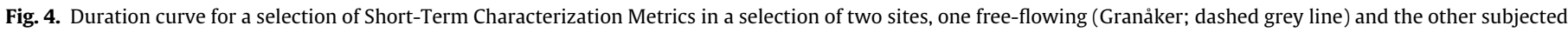
to hydropeaking (Harrsele; solid black line). Abbreviations, units and other information on the STCM are detailed in Table 1.

mainly during summer and autumn, it moderately increased upstream under hydropeaking conditions. No particular seasonal pattern was found for the TSP-I along the upstream sites (Fig. 6). Finally, the impact on the frequencies of the periods of minimum and maximum per day was very low (TMinP-I and TMaxP-I mean close to zero) for all sites (Fig. 6). Impact on the duration related features was the lowest compared to other flow features (Fig. 6). Depending on the metric, the site and the season, hydropeaking resulted in shorter or longer hourly events than in natural conditions (Fig. 6). Events of rise and fall (DurRP-I and DurFP-I) were moderately shorter in all sites affected by hydropeaking than in the free-flowing ones, but the highest impacts occurred during spring for the rise events, and during autumn and winter for the fall events (Fig. 6). The daily duration of the periods of stability, minimum and maximum (DurSP-I, DurMinP-I and DurMaxP-I) hardly differed between hydropeaking and free-flowing conditions, and in general, minor changes on these features occurred predominantly during winter and spring (Fig. 6). Finally, impact on the magnitude and rate related features was the highest (Fig. 6). The impact on the magnitude of the flows characterizing periods of daily maximum and minimum and of the hourly rise rates (MeanMinSP-I, MeanMaxSP-I and MeanRR-I) varied with seasons.
For example, hydropeaking increased moderately the maximum hourly flows during autumn and winter, whereas it hardly decreased them during spring and summer. In contrast, hydropeaking moderately decreased the minimum hourly flows and strongly increased the hourly rise rates in all seasons but winter (Fig. 6). The impact on the mean amplitude and the mean hourly fall rates (MeanA-I and MeanFR-I) was strong regardless of the season, and except for the MeanA-I, which was slightly more affected downstream, all magnitude and rate related metrics were similarly impacted in all sites (Fig. 6).

\subsection{Classification of sites based on short-term alteration of flow regimes}

When averaging the absolute values for the annually averaged STIM (for all metrics or for each subset referred to each flow feature), the intensity of the impact ranged between 0 and 1.05 . Hence, the simplest classification of the sites was based on the impact type and intensity, and regardless of the sign and the timing, and consisted of four categories: free-flowing (0), slightly impacted $(<0.25)$, moderately impacted $(0.26-0.51)$, highly impacted $(0.52-$ $0.77)$, and strongly impacted (0.78-1.05; Fig. 7$)$. The flow regime 

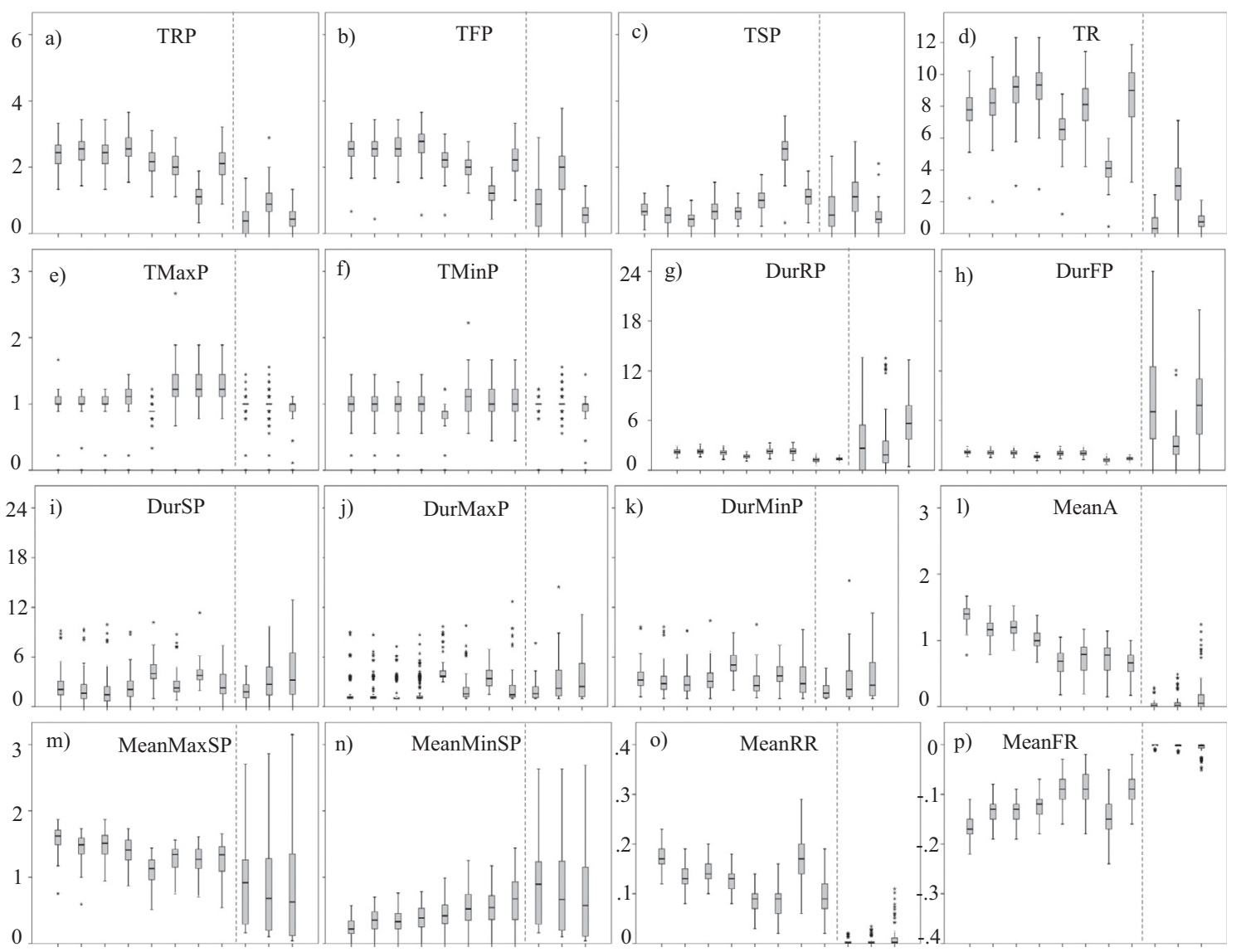

H N O T B L R G U S K
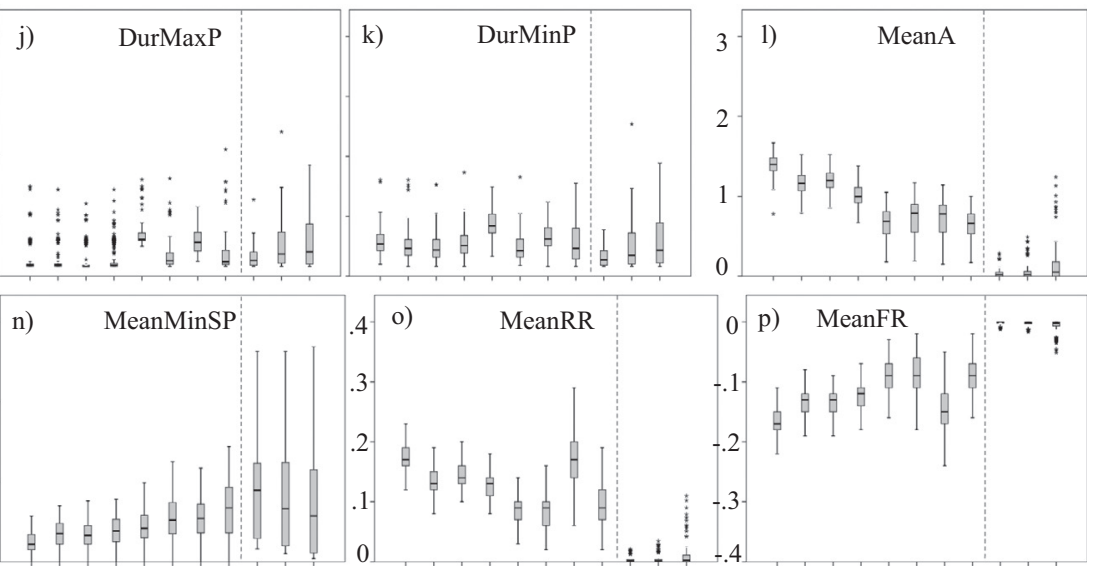

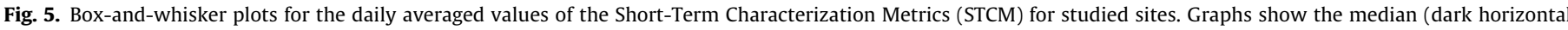

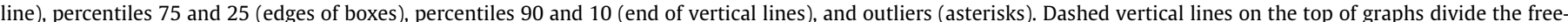

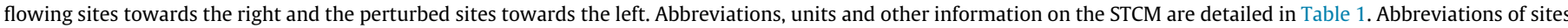
are detailed in Table 3. Graphs a- $\mathrm{f}$ show the frequency related metrics, g- $\mathrm{k}$ show the duration related metrics, and $\mathrm{l}-\mathrm{p}$ show the magnitude and rate related metrics.

in Grundfors (most upstream site) was least impacted for any of the features analyzed. It was followed by Rusfors, whose short-term flow regime was moderately impacted in terms of frequencies and durations, but strongly impacted in terms of magnitudes and rates. The short-term flow regimes of remaining sites were strongly impacted for magnitudes and rates, relatively highly impacted for frequencies, and moderately for durations (Fig. 7). Finally, the seasonality of the hydropeaking impact was corroborated by the most comprehensive classification of the sites, i.e., the hierarchical classification. Between three and five groups resulted from the dendrograms (distance 4 ) according to the type, intensity and sign of the impact on each season's short-term flow regime (Table 3; Supplementary information S7). This classification showed that, except for the frequency related metrics, the impact strongly varied with season (Table 3). In general, from the lowest to the strongest impact, groups based on the impact on frequencies distinguished between sites regardless of the season, i.e., Grundfors, Rusfors, and the remaining downstream sites. Groups based on the impact on magnitudes and on all features together distinguished between seasons regardless of the sites, i.e., in general, the short-term flows from any site in winter, autumn, spring and summer. Finally, groups based on the impact on durations combined sites and seasons (Table 3; Supplementary information S7).

\section{Discussion}

Whereas many studies up to date have dealt with seasonal and annual flow patterns (Clausen and Biggs, 2000; Harris et al. 2000;
Black et al. 2005; Moliere et al. 2009; Bejarano et al. 2010; Kennard et al. 2010; McManamay et al. 2012), few methods adopt data at such a high resolution that is necessary for understanding the within-day hydrograph. Despite short-term flow analysis being viable with shorter hydrological series than those typically needed to assess seasonal or annual flow patterns (Bevelhimer et al. 2015), the limited availability of hourly and sub-hourly stream flow records and the laborious processing required by such large volume of data have been a handicap for studies at finer resolutions. Moreover, although government agencies from several countries and hydropower companies are recently making their instantaneous flow records available [e.g., the USGS Current Water Data for the Nation (EEUU); the Swedish Meteorological and Hydrological Institute and some Swedish hydropower companies; the Norwegian Water Resources and Energy Directorate; the Rete di Monitoraggio in Tempo Reale dell'Ufficio Dighe (Italy); the Federal Office for the Environment (BAFU; Switzerland), among others], there is still a lack of tools supporting their treatment (but see, for example, Sauterleute and Charmasson 2014; Haas et al. 2014). For our purpose, the Vindel and Ume rivers in northern Sweden were excellent study areas. The long series of sub-daily flow records available provided a wide range of scenarios of short-term flow patterns, as they came from free-flowing sites (the Vindel River) and from sites used for hydropower production (the Ume River). Furthermore, as both rivers originally had similar hydrological and physiographical characteristics, the space-by-time method is viable for alteration assessment of the Ume River sites, using the Vindel River as reference. In fact, this pair of rivers has been successfully used in several 

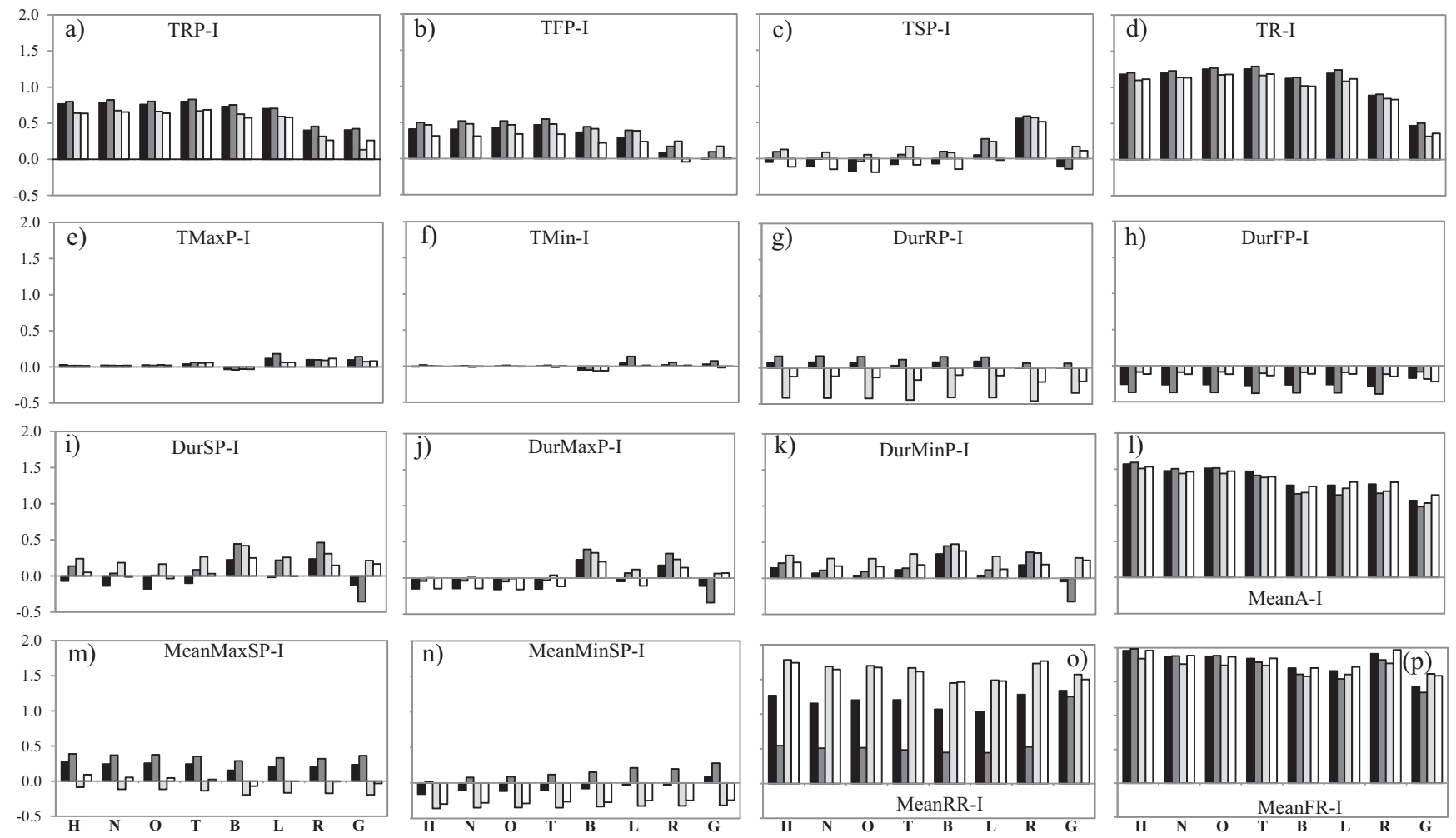

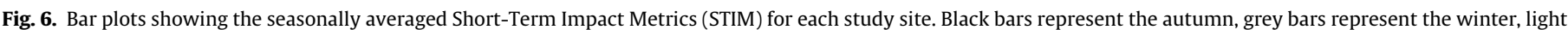

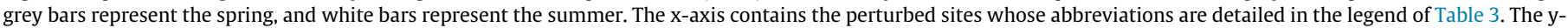

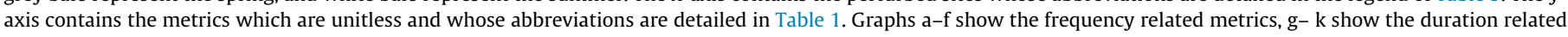
metrics, and $\mathrm{l}-\mathrm{p}$ show the magnitude and rate related metrics.

previous comparative studies (Nilsson et al., 1991; Merritt et al., 2010). The data treatment tool we developed also speeded up metric calculations. Nevertheless, while short-term flows are usually recorded at hydropower plants, we are aware of that recorded data from comparable pristine conditions are not commonly found elsewhere. In these cases, applying the approach would involve the restitution of the natural short-term flow regime at the plant location, or the generation of flows at the desired short-term resolution for a long period based on commonly available daily flows (recorded or modeled) and assuming similar within-day flow variability than the one from, at least, a representative year of recorded data. Minute- or hourly-flows and levels may be measured relatively cheap and easy using pressure-transducer loggers.

One of the common examples of short-term flow regime alterations is hydropower production through peaking plants. The recent increase in hydropower production worldwide has triggered an interest in short-term flow regimes, as these are highly affected by hydropeaking and in recognition of their influence on fluvial ecosystems. However, many studies still have a narrow scope dealing with a small and biased group of metrics (Meile et al., 2011; Zimmerman et al., 2010; Carolli et al., 2015), as long as they are essential for a target species, usually fish (Halleraker et al., 2003), or include larger but still insufficient numbers to account for every ecologically relevant aspect of the sub-daily flow regime (Haas et al., 2014; Sauterleute and Charmasson, 2014; Bevelhimer et al., 2015; Chen et al., 2015). Our proposed metrics have been carefully thought out to enable capturing the full range of within-day hydrological facets which may potentially influence any of the elements (biotic and abiotic) of the fluvial ecosystem, at any time of the life-cycle of different individuals. These metrics provide information on frequency, duration, magnitude, rate of change and timing of daily events characterized by rise, fall or stability trends of flow, or by extreme (maximum or minimum) flows. All of them have been proved to be key for functions of the ecosystem. For example, rapid dewatering was shown to increase the stranding risk of adult fish resulting in higher mortalities (Saltveit et al., 2001; Scruton et al., 2005 and Scruton et al., 2008), increase riparian plant seedling mortality (Stella et al., 2010) and slow down their growth (Amlin and Rood, 2002), and favor sandbar erosion ultimately impacting biological communities because of habitat loss (Álvarez and Schmeeckle, 2013). In addition, high daily flow fluctuations were shown to decrease adult fish size (Dibble et al., 2015), whereas increases in frequency, duration and depth of daily inundations resulted in a reduction of diversity of plant communities by hindering seed germination (Sarneel et al., 2014) and seedling growth (Baldwin et al., 2001). The magnitude and duration of water releases from the power plant also caused considerable losses from benthic populations to drift (Bruno et al., 2010) (See literature reviewed in Table 2). Consequently, all devised metrics are worth keeping as long as they all have ecological importance. Given that our proposed methodology may be potentially used in any context of short-term flow regime characterization and impact assessment, even metrics that hardly differed between our testing sites might be significantly altered in other cases.

The productivity limitations of hydropower plants (in accordance with, e.g., the characteristics of the turbines, dam height or reservoir storage capacity), together with the variable demand for hydroelectricity (in accordance with, e.g., the availability of other energy sources and with daytime and season) (source: U.S. Energy Information Administration; http://www.eia.gov/) result into highly variable operation schemes (i.e., forms of hydropeaking), involving different intensities of production and frequencies and durations of periods of production over time. Furthermore, 

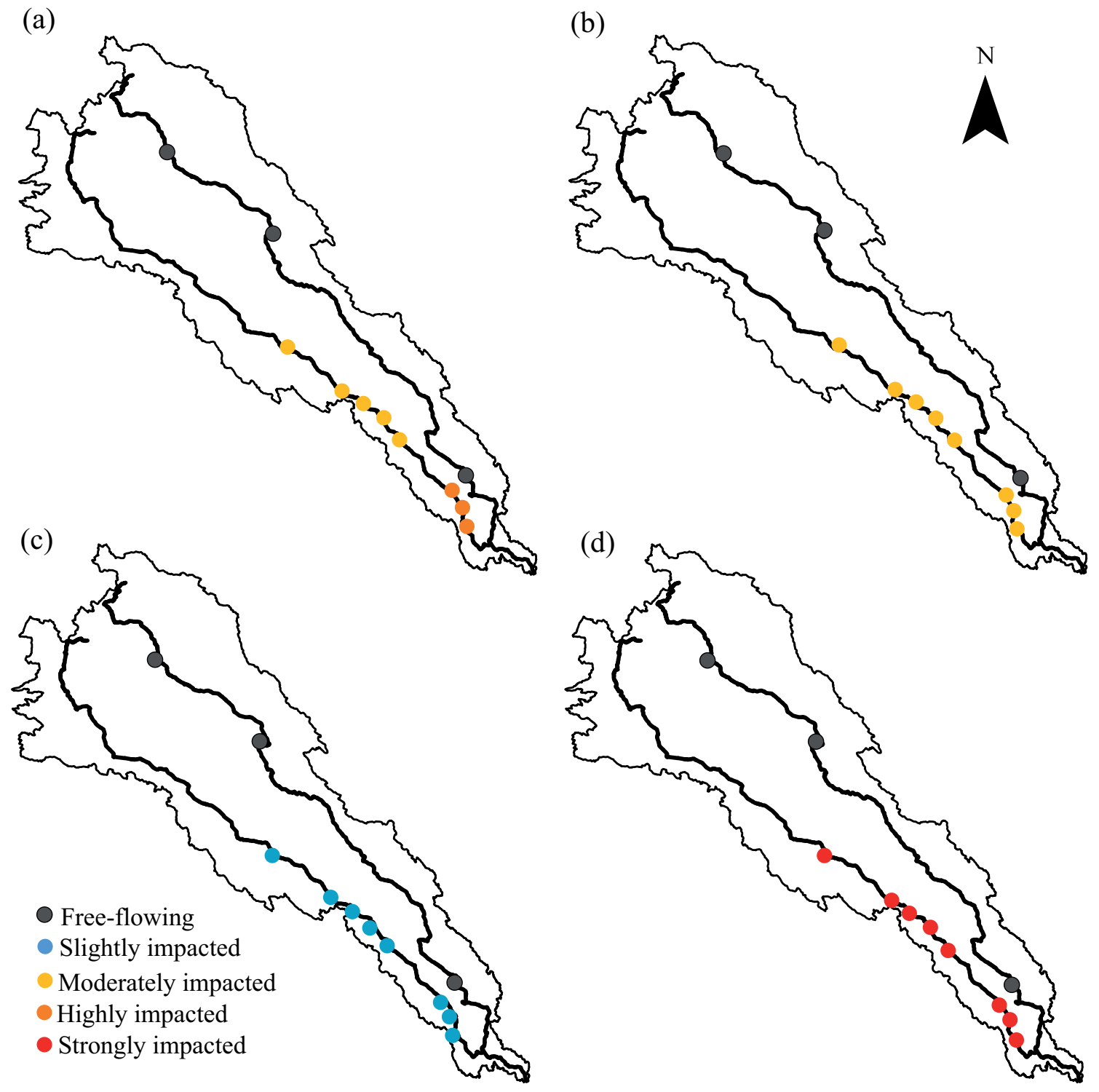

$60 \mathrm{~km}$

ᄂ11-1

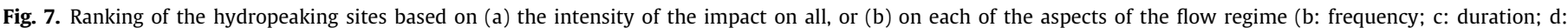

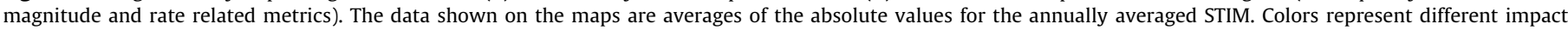
intensities: grey $(=0)$, blue $(<0.25)$, yellow $(0.26-0.51)$, orange $(0.52-0.77)$, and red $(0.78-1.05)$. Sites can be consulted in Fig. 1 .

temporal patterns in power plant operation are superimposed on the natural temporal variability exhibited by the flow regimes of some river types. Consequently, similar operating rules may result in different impacts on flows depending on, e.g., daytime, weekday or season. Therefore, an added value of our devised metrics is that they are able to discern not only which flow features, but also to what degree, how and when they are altered, being able to accurately characterize and evaluate any form of hydropeaking. Budget constraints may lead us to focus mitigation measures on a single, the most affected flow attribute. Alternatively, one may be only interested in restoring a flow attribute because it is key for a target species which is particularly sensitive at a specific moment of its life cycle. Therefore, consideration of impact type, intensity, sign and timing helps targeting of management, making it more feasible and cost-effective. For example, operational mitigation measures involving flow management to ensure proper growth of riparian seedlings should be focused on decreasing flooding duration early in the growing season where this attribute is particularly altered (Gorla et al., 2015). This would be the case of our studied upstream regulated sites, where hydropeaking leads to slightly longer within-day periods of high flows. Other examples involve defining mitigation measures to impede fish stranding, which has been widely documented as the main reason for fish mortality along reaches affected by hydropeaking (see reviews by Nagrodski et al., 2012 and Irvine et al., 2015). As observed in many studies (Saltveit et al., 2001; Scruton et al., 2005, 2008), the response of fish to remain relatively sedentary in winter under varying flows, may increase the likelihood for dewatering, stranding and freezing leading to higher mortality. In winter, energy reserves are depleted and any activity and/or stress related to hydropeaking may potentially affect production and survival. River morphology also plays a relevant role as stranding risk has been recently reported higher along braided compared to single-thread rivers (Vanzo et al., 2015). Mitigation proposals to favor fish populations in the studied 
Table 3

Summary of groups resulting from the cluster classification of the river sites subjected to hydropower production (H: Harrsele; N: Bjurfors nedre; O: Bjurfors övre; T: Tuggen; B: Betsele; L: Bålforsen; R: Rusfors; G: Grundfors) according to their seasonally averaged Short-Term Impact Metrics. Table shows groups from dendrograms at a selected distance 4. Classifications were based on the pool of all metrics regardless the hydrological feature they refer to (first column), and on the sub-set of metrics referring exclusively to frequency (second row), duration (third row), and magnitude and rate (fourth row) related features. Dendrograms may be checked in Supplementary information S7.

Classification according to impact on metrics related to:

Frequency, duration, magnitude and rates

$\begin{array}{ll} & \text { (ii) } \\ & (\mathrm{vi}) \\ & (\mathrm{v}) \\ \text { Frequency } & (\mathrm{i}) \\ & (\mathrm{ii}) \\ \text { Duration } & (\mathrm{iii}) \\ & (\mathrm{i}) \\ & \\ & \text { (ii) } \\ & \text { (iii) } \\ \text { Magnitude and rates } & \text { (iv) } \\ & \text { (i) } \\ & \text { (ii) } \\ & \text { (iii) }\end{array}$

(iii)
Group

(i)

(v)

(ii)

(ii)

iv)

(i)

Sites Seasons

H, N, O, T, B, L

$\mathrm{H}, \mathrm{N}, \mathrm{O}, \mathrm{T}, \mathrm{B}, \mathrm{L}$

$\mathrm{H}, \mathrm{N}, \mathrm{O}, \mathrm{T}, \mathrm{B}, \mathrm{L}, \mathrm{R}$

$\mathrm{R}$

G

G

H, N, O, T, B, L, R, G

G

B, R

G

$\mathrm{H}, \mathrm{N}, \mathrm{O}, \mathrm{T}, \mathrm{B}, \mathrm{L}, \mathrm{R}, \mathrm{G}$

$\mathrm{H}, \mathrm{N}, \mathrm{O}, \mathrm{T}, \mathrm{L}$

$\mathrm{H}, \mathrm{N}, \mathrm{O}, \mathrm{T}, \mathrm{L}$

G

H, N, O, T, B, L, R, G H, N, O, T, B, L, R, G G

H, N, O, T, B, L, R
Spring and summer

Autumn

Winter

Autumn, spring and summer

Spring and summer

Autumn and winter

Autumn, winter, spring and summer

Autumn, winter, spring and summer

Autumn, winter, spring and summer

Autumn, winter and summer

Summer

Spring

Winte

Autumn and summe

Autumn and winter

Spring and summer

Autumn

Winter

Winter reach from the Ume River should involve decreasing numbers of fall events and flow fall rates during winter mainly along the more morphologically complex downstream sites. Magnitude alterations of sub-daily flow events may be important for sessile species, such as plants or macroinvertebrates. Riparian species naturally growing along the upper riparian zone experience sporadic flooding, whereas aquatic and amphibious plants growing further down in the riparian zone face almost constant inundation (Colmer and Voesenek, 2009). Wide ranges of within-day flows, as in rivers subjected to hydropeaking, expose aquatic and riparian-terrestrial plants to frequent variation between drainage and flooding, which impacts riparian areas (Havens et al,. 2004; Bailey-Serres and Voesenek, 2008). This effect is particularly strong in the downstream sites of our study, where measures aimed at narrowing within-day flow ranges are expected to benefit riparian ecosystems.

Existing approaches aimed at evaluating hydropeaking impacts on sub-daily flow regimes only consider a few metrics (Carolli et al., 2015). Others were primarily developed for characterization of short-term flows, and although they might be suitable also for impact assessment, this is not straightforward (Zimmerman et al., 2010; Meile et al., 2011). More comprehensive approaches such as those of Sauterleute and Charmasson (2014) and Chen et al. (2015) are well suited to describe short-term flow regimes affected by hydropeaking, but they are inadequate for detecting alterations. Furthermore, neither of these methods can quantify the various temporal aspects of variability. Only the Wavelet Transform approach is applicable to assess alterations with time, but emphasizes the identification of impacted time scales (White et al., 2005). Our proposed approach overcomes these drawbacks by characterizing both free-flowing and perturbed sub-daily flows and assessing their impact with time, through several ecologically meaningful metrics. In addition, metrics may be easily transformed to stage when the input is a stage series recorded every hour or less. This is interesting when investigating the effects of hydropeaking on riparian ecosystems, given that plants are sessile organisms fully dependent on water-level fluctuations. Finally, proposed classifications help identify sites which have the same short-term flow regime alterations and, consequently, similar management might be recommended for the entire group. According to our results from the most comprehensive site classification, in general, operational mitigation measures could be similar for all power plants downstream of Bålforsen only differing depending on the season, but should be specifically adapted to each of the two remaining upstream plants (i.e., Grundfors and Rusfors) being the same during the whole year. Management groups of sites, however, would be others if certain flow features were the objective of the management action. The goal of the approach is to be useful for the sustainable water management planning, which must consider flow variability at time scales from minutes to decades, as time is widely recognized as the fourth dimension influencing fluvial ecosystems (Ward, 1989; Poff et al., 1997; Biggs et al., 2005). It may be particularly helpful in river basins used for hydropower production. Studies like this can inform decision making on restoring river reaches affected by hydropeaking, relicensing or increasing the capacity of already existing hydropower plants such as in Europe or North America, or evaluating the convenience of new developments as it is the case of Asia, Africa and South America. For example, the economic benefits from hydropower generation along the Mekong or Amazon rivers should be carefully evaluated against the potentially irreversible loss of ecosystem services such as loss of fisheries, removal of wetlands and loss of inundated forests, or effects on food security (Grumbine and Xu, 2011; Lees et al., 2016). This begins by analyzing the impacts of different production (i.e., economic) scenarios on flows at all time scales, and continues with the evaluation of their ecological and societal consequences. For the former, our approach would complement studies on daily, monthly or seasonal basis (Räsänen et al., 2012; Kuenzer et al., 2013). For the latter, further research should provide knowledge on relationships between sub-daily flows and ecology (and society). Overall, harmonizing hydroelectricity production and fluvial ecosystem sustainability is a challenging demand for industry and society, and studies like this are absolutely needed.

\section{Conclusions}

The approach presented in this article, which encompasses devising new characterization metrics and the adaptation of evaluation and classification methods standardly used in ecology, represents a breakthrough in the still poorly studied field of shortterm flows. It has been conceived to support the sustainable water 
management in rivers subjected to hydropower production, and in general in rivers whose sub-daily flows are altered by any other cause. It may also help directing measures of fluvial restoration to particularly impacted river reaches, flow features and seasons. It could also serve public authorities during flow regulation relicensing or evaluating processes of new projects. Site-specificity of water-stage results in complex relationships between this variable and hydropeaking. Therefore, future research should address characterization, impact assessment and classification of shortterm water-level regimes, which are key when analyzing potential impacts of hydropower production on riparian zones. In addition, our approach should be extended to other river reaches worldwide, as different operating schemes on different river types may lead to different impact ranges from those obtained here. High impacts in snowmelt-fed rivers are due to the natural stability of stream flows, but we might expect much lower impacts in, e.g., Mediterranean rivers given their great dynamics even under natural conditions (Gasith and Resh, 1999). A global application would also generate a global database of sub-daily flow-regime types and impacts providing objective information necessary for categorization of river reaches worldwide. Finally, ecological implications of described sub-daily flow changes still need to be sorted out (Poff et al., 2010).

\section{Acknowledgments}

The authors would like to thank the Swedish Meteorological Agency -SMHI- and Statkraft Sverige AB, Vattenfall AB, E.ON Vattenkraft Sverige $A B$, Vattenfall Vattenkraft $A B$ and Vattenfall Umeälven $A B$ power companies, for providing the series of instantaneous flows. Roland Jansson is gratefully acknowledged for his valuable comments during the study process. The research leading to these results was funded by the EU-FP7-PEOPLE Marie Curie IEF actions under the grant agreement no 623691 (RiPeak: "Responses of RiParian forests to hydroPeaking: towards a sustainable hydropower management"; http://cordis.europa.eu/project/rcn/187789_es. html). Funds from Fundación José Entrecanales Ibarra also supported part of the research.

\section{Appendix A. Supplementary data}

Supplementary data associated with this article can be found, in the online version, at http://dx.doi.org/10.1016/j.jhydrol.2017.04. 023.

\section{References}

Álvarez, L.V., Schmeeckle, M.W., 2013. Erosion of river sandbars by diurnal stage fluctuations in the Colorado River in the Marble and Grand Canyons: full-scale laboratory experiments. River Res. Appl. 29, 839-854.

Amlin, N.M., Rood, S.B., 2002. Comparative tolerances of riparian willows and cottonwoods to water-table decline. Wetlands 22, 338-346.

Archer, D., Newson, M., 2002. The use of indices of flow variability in assessing the hydrological and instream habitat impacts of upland afforestation and drainage. J. Hydrol. 268, 244-258.

Armstrong, W., Brändle, R., Jackson, M.B., 1994. Mechanisms of flood tolerance in plants. Acta Bot. Neerl. 43, 307-358.

Armstrong, J.D., Kemp, P.S., Kennedy, G.J.A., Ladle, M., Milner, N.J., 2003. Habitat requirements of Atlantic salmon and brown trout in rivers and streams. Fish. Res. $62,143-170$.

Bailey-Serres, J., Voesenek, L.A.C.J., 2008. Flooding stress: acclimations and genetic diversity. Ann. Rev. Plant Biol. 59, 313-339.

Baker, D.B., Richards, R.P., Loftus, T.T., Kramer, J.W., 2004. A new flashiness index: characteristics and applications to midwestern rivers and streams. J. Am. Water Resour. Assoc. 40, 503-522.

Baldwin, A.H., Egnotovich, M.S., Clarke, E., 2001. Hydrologic change and vegetation of tidal freshwater marshes: field, greenhouse, and seed-bank experiments. Wetlands 21, 519-531.

Bejarano, M.D., Marchamalo, M., de Jalón, D.G., del Tánago, M.G., 2010. Flow regime patterns and their controlling factors in the Ebro basin (Spain). J. Hydrol. 385, 323-335.
Bevelhimer, M.S., McManamay, R.A., O'Connor, B., 2015. Characterizing sub-daily flow regimes: implications of hydrologic resolution on ecohydrology studies. River Res. Appl. 31, 867-879.

Biggs, B.J., Nikora, V.I., Snelder, T.H., 2005. Linking scales of flow variability to lotic ecosystem structure and function. River Res. Appl. 21, 283-298.

Black, A.R., Rowan, J.S., Duck, R.W., Bragg, O.M., Clelland, B.E., 2005. DHRAM: a method for classifying river flow regime alterations for the EC Water Framework Directive. Aquat. Conserv.-Mar. Freshwater Ecosyst. 15, 427-446.

Boavida, I., Santos, J.M., Ferreira, T., Pinheiro, A., 2015. Barbel habitat alterations due to hydropeaking. J. Hydro-environ. Res. 9, 237-247.

Boavida, I., Harby, A., Clarke, K.D., Heggenes, J., 2017. Move or stay: habitat use and movements by Atlantic salmon parr (Salmo salar) during induced rapid flow variations. Hydrobiologia 785, 261-275.

Boedeltje, G.E.R., Bakker, J.P., Ten Brinke, A., Van Groenendael, J.M., Soesbergen, M. 2004. Dispersal phenology of hydrochorous plants in relation to discharge, seed release time and buoyancy of seeds: the flood pulse concept supported. J. Ecol 92, 786-796.

Bruno, M.C., Maiolini, B., Carolli, M., Silveri, L., 2010. Short time-scale impacts of hydropeaking on benthic invertebrates in an alpine stream (Trentino, Italy) Limnologica 40, 281-290.

Bruno, M.C., Cashman, M.J., Maiolini, B., Biffi, S., Zolezzi, G., 2016. Responses of benthic invertebrates to repeated hydropeaking in semi-natural flume simulations. Ecohydrology 9, 68-82.

Bruton, M.N., 1985. The effects of suspended solids on fish. Hydrobiologia 125, 221-241.

Capra, H., Plichard, L., Bergé, J., Pella, H., Ovidio, M., McNeil, E., Lamouroux, N., 2016. Fish habitat selection in a large hydropeaking river: strong individual and temporal variations revealed by telemetry. Sci. Total Environ. 578, 109-120.

Carlisle, D.M., Wolock, D.M., Meador, M.R., 2011. Alteration of streamflow magnitudes and potential ecological consequences: a multiregional assessment. Front. Ecol. Environ. 9, 264-270.

Carolli, M., Bruno, M.C., Siviglia, A., Maiolini, B., 2012. Responses of benthic invertebrates to abrupt changes of temperature in flume simulations. River Res. Appl. 28, 678-691.

Carolli, M., Vanzo, D., Siviglia, A., Zolezzi, G., Bruno, M.C., Alfredsen, K., 2015. A simple procedure for the assessment of hydropeaking flow alterations applied to several European streams. Aquat. Sci. 77, 639-653.

Casanova, M.T., Brock, M.A., 2000. How do depth, duration and frequency of flooding influence the establishment of wetland plant communities? Plant Ecol. 147, 237-250.

Casas-Mulet, R., Saltveit, S.J., Alfredsen, K., 2015. The survival of Atlantic salmon (Salmo salar) eggs during dewatering in a river subjected to hydropeaking. River Res. Appl. 31, 433-446.

Castro, D.M., Hughes, R.M., Callisto, M., 2013. Effects of flow fluctuations on the daily and seasonal drift of invertebrates in a tropical river. Ann. Limnol. Int. J. Limnol. 49, 169-177.

Chen, Q., Zhang, X., Chen, Y., Li, Q., Qiu, L., Liu, M., 2015. Downstream effects of a hydropeaking dam on ecohydrological conditions at sub-daily to monthly time scales. Ecol. Eng. 77, 40-50.

Clausen, B., Biggs, B.J.F., 2000. Flow variables for ecological studies in temperate streams: groupings based on covariance. J. Hydrol. 237, 184-197.

Colmer, T.D., Voesenek, L.A.C.J., 2009. Flooding tolerance: suites of plant traits in variable environments. Funct. Plant Biol. 36, 665-681.

Cowx, I.G., O'Grady, K.T., O'Connor, W.C.K., Andrew, T.E., 1998. The effects of siltation on Atlantic salmon, Salmo salar L., embryos in the River Bush. Fisheries Manage. Ecol. 5, 393-401.

Dibble, K.L., Yackulic, C.B., Kennedy, T.A., Budy, P., 2015. Flow management and fish density regulate salmonid recruitment and adult size in tailwaters across western North America. Ecol. Appl. 25, 2168-2179.

Directive 2009/28/EC of the European Parliament and of the Council of 23 April 2009 on the promotion of the use of energy from renewable sources. Brussels

Elliott, J.M., Hurley, M.A., Elliott, J.A., 1997. Variable effects of droughts on the density of a sea-trout population over 30 years. J. Appl. Ecol. 34, 1229-1238.

Ernst, W.H.O., 1990. Ecophysiology of plants in waterlogged and flooded environments. Aquat. Bot. 38, 73-90.

European Greenpower Marketing. 2006. Hervorragende Aussichten für Wasserkraft: <www.greenpowermarkets.eu/>.

Fitzhugh, T.W., Vogel, R.M., 2011. The impact of dams on flood flows in the United States. River Res. Appl. 27, 1192-1215.

Flodmark, L.E.W., Vollestad, L.A., Forseth, T., 2004. Performance of juvenile brown trout exposed to fluctuating water level and temperature. J. Fish Biol. 65, 460-470.

Freeman, M.C., Bowen, Z.H., Bovee, K.D., Irwin, E.R., 2001. Flow and habitat effects on juvenile fish abundance in natural and altered flow regimes. Ecol. Appl. 11, $179-190$.

Friedman, J.M., Auble, G.T., 1999. Mortality of riparian box elder from sediment mobilization and extended inundation. Regul. Rivers- Res. Manage. 15, 463-476.

Gao, Y., Vogel, R.M., Kroll, C.N., Poff, N.L., Olden, J.D., 2009. Development of representative indicators of hydrologic alteration. J. Hydrol. 374, 136-147.

Garcia de Jalón, D., Montes, C., Barcelo, E., Casado, C., Menes, F., 1998. Effects of hydroelectric scheme on fluvial ecosystems within the Spanish Pyrenees. Regul. Rivers-Res. Manage. 2, 479-491.

Gasith, A., Resh, V.H., 1999. Streams in Mediterranean climate regions: abiotic influences and biotic responses to predictable seasonal events. Ann. Rev. Ecol. Syst. 30, 51-81.

Goodson, J.M., Gurnell, A.M., Angold, P.G., Morrissey, I.P., 2003. Evidence for hydrochory and the deposition of viable seeds within winter flow-deposited sediments: the River Dove, Derbyshire. UK. River Res. Appl. 19, 317-334. 
Gorla, L., Signarbieux, C., Turberg, P., Buttler, A., Perona, P., 2015. Transient response of Salix cuttings to changing water level regimes. Water Resour. Res. 51, 1758 1774.

Gostner, W., Lucarelli, C., Theiner, D., Kager, A., Premstaller, G., Schleiss, A., 2011. A holistic approach to reduce negative impacts of hydropeaking. In: Schleiss, A.J., Boes, R.N. (Eds.), Dams and Reservoirs Under Changing Challenges. CRC Press, Boca Raton, pp. 857-866.

Grumbine, R.E., Xu, J., 2011. Mekong hydropower development. Science 332, 178 179.

Haas, N.A., O'Connor, B.L., Hayse, J.W., Bevelhimer, M.S., Endreny, T.A., 2014 Analysis of daily peaking and run-of-river operations with flow variability metrics, considering subdaily to seasonal time scales. J. Am. Water Resour. Ass. $50,1622-1640$

Halleraker, J.H., Saltveit, S.J., Harby, A., Arnekleiv, J.V., Fjeldstad, H.P., Kohler, B. 2003. Factors influencing stranding of wild juvenile brown trout (Salmo trutta) during rapid and frequent flow decreases in an artificial stream. River Res. Appl. 19, 589-603.

Harris, N.M., Gurnell, A.M., Hannah, D.M., Petts, G.E., 2000. Classification of river regimes: a context for hydroecology. Hydrol. Proc. 14, 2831-2848.

Hauer, C., Unfer, G., Holzapfel, P., Haimann, M., Habersack, H., 2014. Impact of channel bar form and grain size variability on estimated stranding risk of juvenile brown trout during hydropeaking. Earth Surf. Processes Landforms 39, 1622-1641.

Havens, K.E., Sharfstein, B., Brady, M.A., East, T.L., Harwell, M.C., Maki, R.P., Rodusky, A.J., 2004. Recovery of submerged plants from high water stress in a large subtropical lake in Florida, USA. Aquat. Bot. 78, 67-82.

Heggenes, J., Alfredsen, K., Adeva Bustos, A., Huusko, A., 2016. Be cool: hydrophysical changes and fish responses in winter in hydropower-regulated northern streams. Publication series from the University College of Southeast Norway no 1, Kongsberg.

Holzapfel, P., Leitner, P., Habersack, H., Graf, W., Hauer, C., 2016. Evaluation of hydropeaking impacts on the food web in alpine streams based on modelling of fish-and macroinvertebrate habitats. Sci. Total Environ. 575, 1489-1502.

Irvine, R.L., Oussoren, T., Baxter, J.S., Schmidt, D.C., 2009. The effects of flow reduction rates on fish stranding in British Columbia, Canada. River Res. Appl $25,405-415$.

Irvine, R.L., Thorley, J.L., Westcott, R., Schmidt, D., DeRosa, D., 2015. Why do fish strand? An analysis of ten years of flow reduction monitoring data from the Columbia and Kootenay rivers, Canada. River Res. Appl. 31, 1242-1250.

Jager, H.I., Efroymson, R.A., Opperman, J.J., Kelly, M.R., 2015. Spatial design principles for sustainable hydropower development in river basins. Renewable Sustainable Energy Rev. 45, 808-816.

Jensen, A.J., Johnsen, B.O., 1999. The functional relationship between peak spring floods and survival and growth of juvenile Atlantic salmon (Salmo salar) and brown trout (Salmo trutta). Funct. Ecol. 13, 778-785.

Kelly, B., Smokorowski, K.E., Power, M., 2017. Impact of river regulation and hydropeaking on the growth, condition and field metabolism of brook trout (Salvelinus fontinalis). Ecol. Freshwater Fish. http://dx.doi.org/ 10.1111/eff.12310

Kennard, M.J., Pusey, B.J., Olden, J.D., MacKay, S.J., Stein, J.L., Marsh, N., 2010 Classification of natural flow regimes in Australia to support environmenta flow management. Freshwater Biol. 55, 171-193.

Kennedy, T.A., Muehlbauer, J.D., Yackulic, C.B., Lytle, D.A., Miller, S.W., Dibble, K.L. Koertenhoeven, E.W. Metcalfe, A., Baxter, C.V., 2016. Flow management for hydropower extirpates aquatic insects, undermining river food webs. Bioscience 66, 561-575.

Kirk, J.T., 1994. Light and Photosynthesis in Aquatic Ecosystems. Cambridge University Press, Cambridge.

Korman, J., Campana, S.E., 2009. Effects of hydropeaking on nearshore habitat use and growth of age-0 rainbow trout in a large regulated river. Trans. Am. Fish. Soc. $138,76-87$.

Kuenzer, C., Campbell, I., Roch, M., Leinenkugel, P., Tuan, V.Q., Dech, S., 2013. Understanding the impact of hydropower developments in the context of upstream-downstream relations in the Mekong river basin. Sustainable Sci. 8, 565-584.

Lees, A.C., Peres, C.A., Fearnside, P.M., Schneider, M., Zuanon, J.A., 2016. Hydropower and the future of Amazonian biodiversity. Biodivers. Conserv. 25 451-466.

Leitner, P., Hauer, C., Graf, W., 2017. Habitat use and tolerance levels of macroinvertebrates concerning hydraulic stress in hydropeaking rivers: a case study at the Ziller River in Austria. Sci. Total Environ. 575, 112-118.

Levasseur, M., Bergeron, N.E., Lapointe, M.F., Bérubé, F., 2006. Effects of silt and very fine sand dynamics in Atlantic salmon (Salmo salar) redds on embryo hatching success. Can. J. Fish. Aquat. Sci. 63, 1450-1459.

Lind, L., Nilsson, C. Polvi, L.E., Weber, C., 2014. The role of ice dynamics in shaping vegetation in flowing waters. Biol. Rev. 89, 791-804.

Lundquist, J.D., Cayan, D.R., 2002. Seasonal and spatial patterns in diurnal cycles in streamflow in the western United States. J. Hydrometeorology 3, 591-603.

Lytle, D.H., Poff, N.L., 2004. Adaptation to natural flow regimes. Trends Ecol. Evol. 19 94-100.

Madsen, J.D., Chambers, P.A., James, W.F., Koch, E.W., Westlake, D.F., 2001. The interaction between water movement, sediment dynamics and submersed macrophytes. Hydrobiologia 444, 71-84.

McManamay, R.A., Orth, D.J., Dolloff, C.A., Frimpong, E.A., 2012. A regiona classification of unregulated stream flows: spatial resolution and hierarchica frameworks. River Res. Appl. 28, 1019-1033.
Meile, T., Boillat, J.L., Schleiss, A.J., 2011. Hydropeaking indicators for characterization of the Upper-Rhone River in Switzerland. Aqua Sci. 73, 171182.

Merritt, D.M., Nilsson, C., Jansson, R., 2010. Consequences of propagule dispersal and river fragmentation for riparian plant community diversity and turnover. Ecol. Monogr. 80, 609-626.

Miller, S.W., Judson, S., 2014. Responses of macroinvertebrate drift, benthic assemblages, and trout foraging to hydropeaking. Can. J. Fish. Aquat. Sci. 71, 675-687.

Milner, N.J., Elliott, J.M., Armstrong, J.D., Gardiner, R., Welton, J.S., Ladle, M., 2003. The natural control of salmon and trout populations in streams. Fish. Res. 62, $111-125$.

Mjelde, M., Hellsten, S., Ecke, F., 2013. A water level drawdown index for aquatic macrophytes in Nordic lakes. Hydrobiologia 704, 141-151.

Moliere, D.R., Lowry, J.B., Humphrey, C.L., 2009. Classifying the flow regime of datalimited streams in the wet-dry tropical region of Australia. J. Hydrol. 367, 1-13.

Moog, O., 1993. Quantification of daily peak hydropower effects on aquatic fauna and management to minimize environmental impacts. Regul. Rivers-Res. Manage. 8, $5-14$.

Nagrodski, A., Raby, G.D., Hasler, C.T., Taylor, M.K., Cooke, S.J., 2012. Fish stranding in freshwater systems: sources, consequences, and mitigation. J. Environ. Manage. 103, 133-141.

Nilsson, C., Ekblad, A., Gardfjell, M., Carlberg, B., 1991. Long-term effects of river regulation on river margin vegetation. J. Appl. Ecol. 28, 963-987.

Olden, J.D., Poff, N.L., 2003. Redundancy and the choice of hydrologic indices for characterizing streamflow regimes. River Res. Appl. 19, 101-121.

Pettit, N.E., Naiman, R.J., 2006. Flood-deposited wood creates regeneration niches for riparian vegetation on a semi-arid South African river. J. Veg. Sci. 17, 615-624.

Poff, N.L., Allan, J.D., Bain, M.B., Karr, J.R., Prestegaard, K.L., Richter, B.D., Sparks, R.E., Stromberg, J.C., 1997. The natural flow regime: a paradigm for river conservation and restoration. Bioscience 47, 769-784.

Poff, N.L., Richter, B.D., Arthington, A.H., Bunn, S.E., Naiman, R.J., Kendy, E., Acreman, M., Apse, C., Bledsoe, B.P., Freeman, M., Henriksen, J., Jacobson, R.B., Kennen, J., Merritt, D.M., O'Keeffe, J., Olden, J.D., Rogers, K., Tharme, R.E., Warner, A., 2010. The ecological limits of hydrologic alteration (ELOHA): a new framework for developing regional environmental flow standards. Freshw. Biol. 55, 147-170.

Porporato, A. Laio, F., Ridolfi, L., Rodríguez-Iturbe, I., 2001. Plants in watercontrolled ecosystems: active role in hydrologic processes and response to water stress: III. Vegetation water stress. Adv. Water Resour. 24, 725-744.

Puffer, M., Berg, O.K., Huusko, A., Vehanen, T., Forseth, T., Einum, S., 2015. Seasonal effects of hydropeaking on growth, energetics and movement of juvenile Atlantic salmon (Salmo salar). River Res. Appl. 31, 1101-1108.

Räsänen, T.A., Koponen, J., Lauri, H., Kummu, M., 2012. Downstream hydrological impacts of hydropower development in the Upper Mekong Basin. Water Resour. Manage 26, 3495-3513.

Richter, B., Baumgartner, J., Powell, J., Braun, D., 1996. A method for assessing hydrologic alteration within ecosystems. Conserv. Biol. 10, 1163-1174.

Richter, B.D., Baumgartner, J.V., Wigington, R., Braun, D.P., 1997. How much water does a river need? Freshw. Biol. 37, 231-249.

Robertson, M.J., Pennell, C.J., Scruton, D.A., Robertson, G.J., Brown, J.A., 2004. Effect of increased flow on the behaviour of Atlantic salmon parr in winter. J. Fish Biol. 65, 1070-1079.

Rocaspana, R., Aparicio, E., Vinyoles, D., Palau, A., 2016. Effects of pulsed discharges from a hydropower station on summer diel feeding activity and diet of brown trout (Salmo trutta Linnaeus, 1758) in an Iberian stream. J. Appl. Ichthyol. 32, 190-197.

Roni, P., Hanson, K., Beechie, T., 2008. Global review of the physical and biological effectiveness of stream habitat rehabilitation techniques. N. Am. J. Fish. Manage. $28,856-890$.

Saltveit, S.J., Halleraker, J.H., Arnekleiv, J.V., Harby, A., 2001. Field experiments on stranding in juvenile Atlantic salmon (Salmo salar) and brown trout (Salmo trutta) during rapid flow decreases caused by hydropeaking. Regul. Rivers-Res. Manage. 17, 609-622.

Sarneel, J.M., Janssen, R.H., Rip, W.J., Bender, I., Bakker, E.S., 2014. Windows of opportunity for germination of riparian species after restoring water level fluctuations: a field experiment with controlled seed banks. J. Appl. Ecol. 51, 1006-1014.

Sauterleute, J.F., Charmasson, J., 2014. A computational tool for the characterisation of rapid fluctuations in flow and stage in rivers caused by hydropeaking. Environ. Modell. Softw. 55, 266-278.

Schuster, W.D., Zhang, Y., Roy, A.H., Daniel, F.B., Troyer, M., 2008. Characterizing storm hydrograph rise and fall dynamics with stream gage data. J. Am. Water Resour. Assoc. 44, 1431-1440.

Scruton, D.A., Ollerhead, L.M.N., Clarke, K.D., Pennell, C., Alfredsen, K., Harby, A. Kelley, D., 2003. The behavioural response of juvenile Atlantic salmon (Salmo salar) and brook trout (Salvelinus fontinalis) to experimental hydropeaking on a Newfoundland (Canada) river. River Res. Appl. 19, 577-587.

Scruton, D.A., Pennell, C.J., Robertson, M.J., Ollerhead, L.M.N., Clarke, K.D., Alfredsen, K., Harby, A., McKinley, R.S., 2005. Seasonal response of juvenile Atlantic salmon to experimental hydropeaking power generation in Newfoundland, Canada. N. Am. J. Fish. Manage. 25, 964-974.

Scruton, D.A., Pennell, C., Ollerhead, L.M.N., Alfredsen, K., Stickler, M., Harby, A. Robertson, M., Clarke, K.D., LeDrew, L.J., 2008. A synopsis of 'hydropeaking' studies on the response of juvenile Atlantic salmon to experimental flow alteration. Hydrobiologia 609, 263-275.

Smith, C., Reay, P., 1991. Cannibalism in teleost fish. Rev. Fish Biol. Fish. 1, 41-64. 
Stella, J.C., Battles, J.J., McBride, J.R., Orr, B.K., 2010. Riparian seedling mortality from simulated water table recession, and the design of sustainable flow regimes on regulated rivers. Restor. Ecol. 18, 284-294.

Taylor, M.K., Cooke, S.J., 2012. Meta-analyses of the effects of river flow on fish movement and activity. Environ. Rev. 20, 211-219.

Taylor, M.K., Hasler, C.T., Hinch, S.G., Lewis, B., Schmidt, D.C., Cooke, S.J., 2014. Reachscale movements of bull trout (Salvelinus confluentus) relative to hydropeaking operations in the Columbia River, Canada. Ecohydrology 7, 1079-1086.

Timusk, E.R., Smokorowski, K.E., Jones, N.E., 2016. An experimental test of subhourly changes in macroinvertebrate drift density associated with hydropeaking in a regulated river. J. Freshwater Ecol. 31, 555-570.

Tuhtan, J.A., Noack, M., Wieprecht, S., 2012. Estimating stranding risk due to hydropeaking for juvenile European grayling considering river morphology. KSCE J. Civ. Eng. 16, 197-206.

Van Looy, K., Jochems, H., Vanacker, S., Lommelen, E., 2007. Hydropeaking impact on a riparian ground beetle community. River Res. Appl. 23, 223-233.

Vanzo, D., Zolezzi, G., Siviglia, A., 2015. Eco-hydraulic modelling of the interactions between hydropeaking and river morphology. Ecohydrology 9, 421-437.
Vehanen, T., Jurvelius, J., Lahti, M., 2005. Habitat utilisation by fish community in a short-term regulated river reservoir. Hydrobiologia 545, 257-270.

Vollset, K.W., Skoglund, H., Wiers, T., Barlaup, B.T., 2016. Effects of hydropeaking on the spawning behaviour of Atlantic salmon Salmo salar and brown trout Salmo trutta. J. Fish Biol. 88, 2236-2250.

Ward, J.V., 1989. The four-dimensional nature of lotic ecosystems. J. N. Am. Benthol. Soc. $8,2-8$.

Warren, M., Dunbar, M.J., Smith, C., 2015. River flow as a determinant of salmonid distribution and abundance: a review. Environ. Biol. Fish. 98, 1695-1717.

White, M.A., Schmidt, J.C., Topping, D.J., 2005. Application of wavelet analysis for monitoring the hydrologic effects of dam operation: Glen Canyon Dam and the Colorado River at Lees Ferry, Arizona. River Res. Appl. 21, 551-565.

Wolter, C., Sukhodolov, A., 2008. Random displacement versus habitat choice of fish larvae in rivers. River Res. Appl. 24, 661-672.

Wootton, R.J., 1998. Ecology of Teleost Fishes. Kluwer Academic Publishers, Dordrecht.

Zimmerman, J.K., Letcher, B.H., Nislow, K.H., Lutz, K.A., Magilligan, F.J., 2010 Determining the effects of dams on subdaily variation in river flows at a wholebasin scale. River Res. Appl. 26, 1246-1260. 